\title{
هستوى وعي الأسرة بدورها في رعاية الطفل الموهوب
}

\author{
إعــــــاد \\ د. سميرة احمد حسر العبدل لهـ \\ استاذ مساعد السكن وادارة المنزل

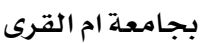

مجلة بحوث التربية النوعية - جامعة المنصورة

العلد الثامن عشر - سبتمبر • r.1 


\section{مستوى وعي الأسرة بدورها في رعاية الطفل الموهوب}

إعــداد

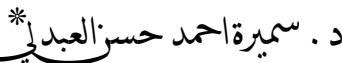

هدفت الدراسـة :إلى التعرف على مستوى وعي الأسـرة بدورها ِِِ رعاية الطفل الموهوب وتأثير

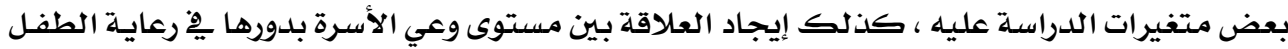

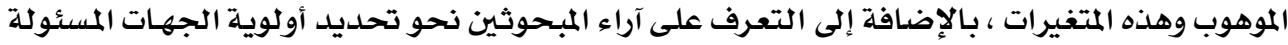

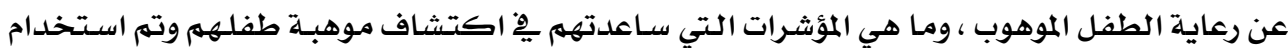

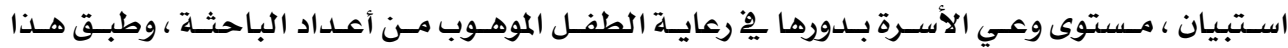

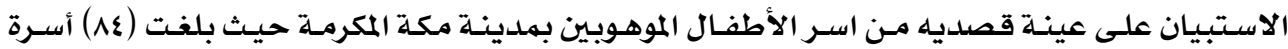
واتبعت الباحثة المنهج الوصفي التحليلي يِّ تحليل النتائج وجاءت أهم النتائج على النحو التالي :-

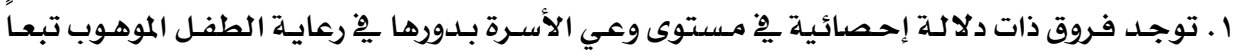

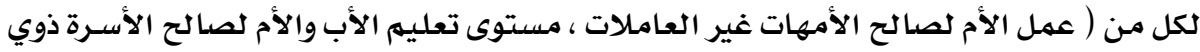

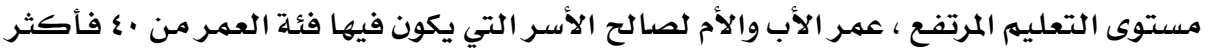

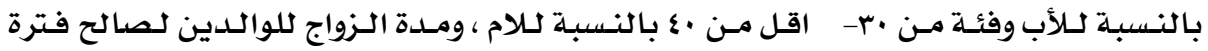

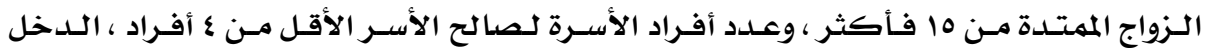

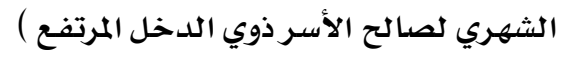

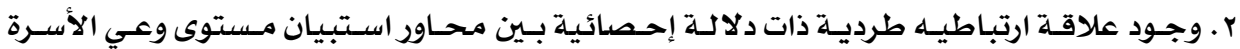

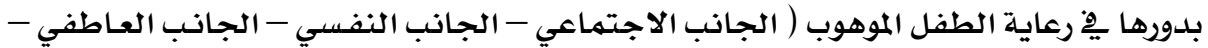

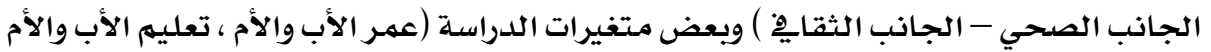

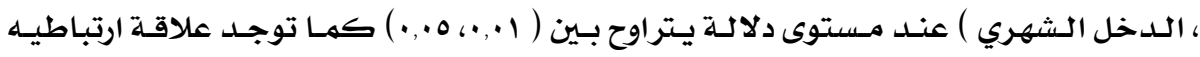

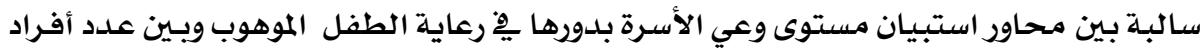

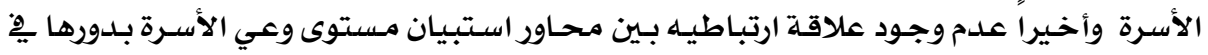
رعاية الطفل الموهوب وكل من مدة الزواج وأعمار العدود الأبناء . r. كان تعليهم الأب أكثر العوامل المؤثرة على وعي الأسـرة بـدورها يِّ رعايـة الطفل الموهـوب يليـه

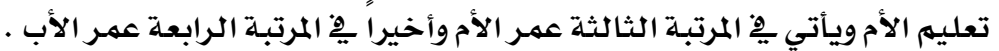




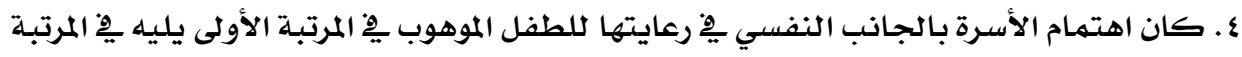

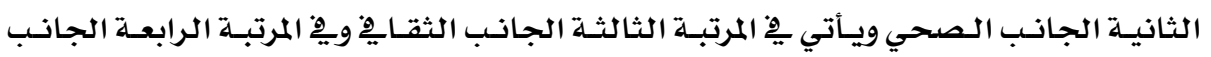

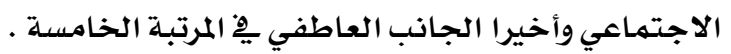

$$
\begin{aligned}
& \text { وجاءت أهم التوصيات على النحو التالي:- }
\end{aligned}
$$

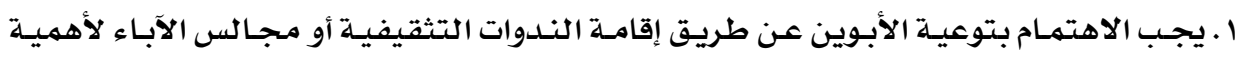

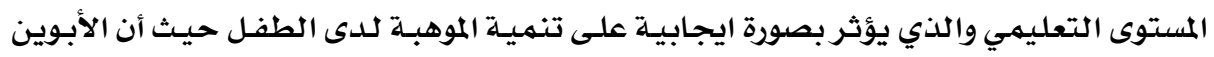

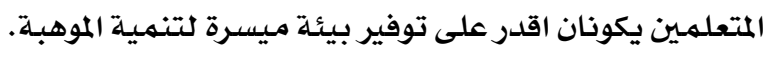

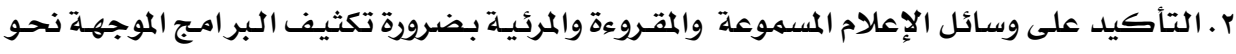

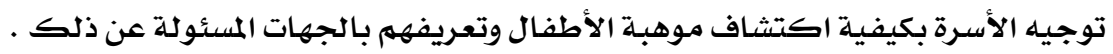

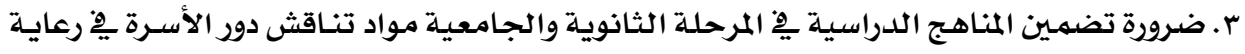

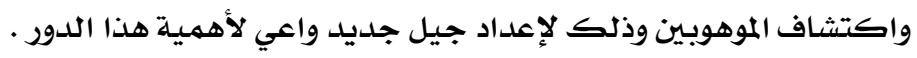




\section{مستوى وعي الأسرة بدورها في رعاية الطفل الموهوب}

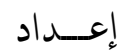

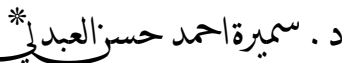

\section{مقدهة ومشكلة البحث}

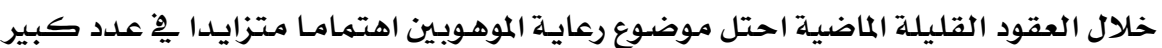

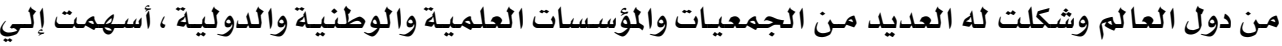

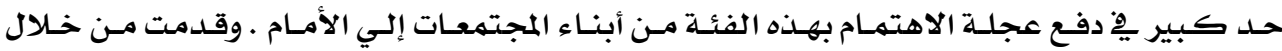

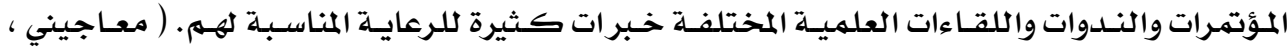

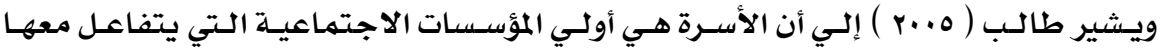

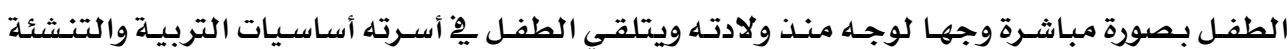

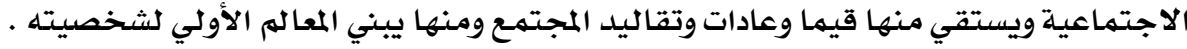

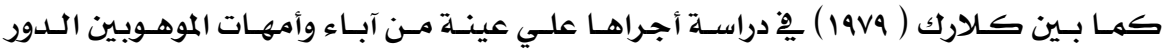

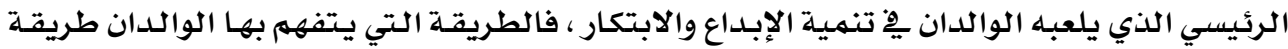

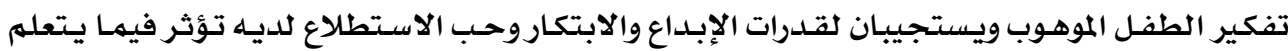

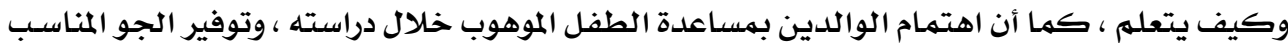

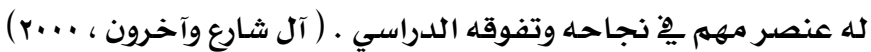

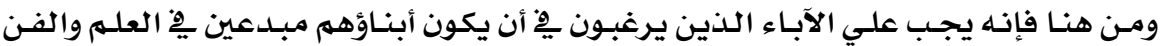

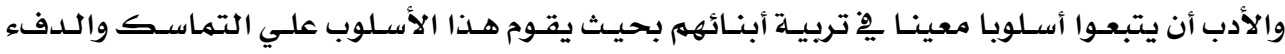
والقبول والحريـة .

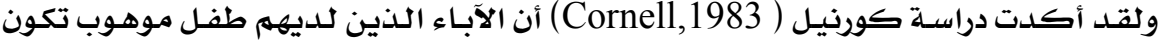

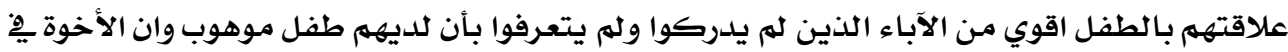

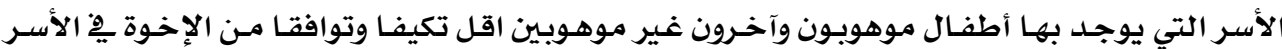

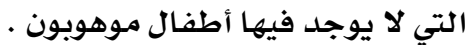
كهـا أن الطريقـة الـتي يــركك بها الوالـدان وأفراد الأسـرة الآخـرون الطفـل الموهـوب الموجـود

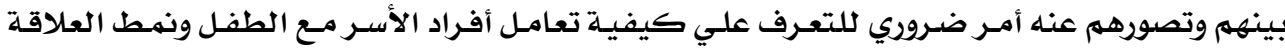

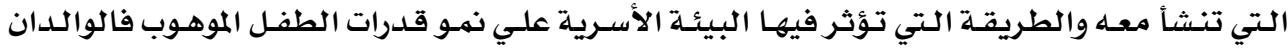

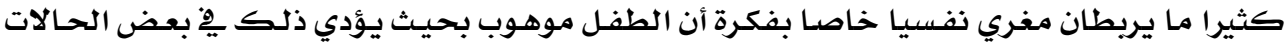


إلي تصور مثالي وغير واقعي للطفل مما يؤدي إلي أضرارومعوقات يِّ تطوره ونهـوه ـ (آل شارع وآخرون

(r....

ويذكر بورتر (Porter,1999) انه بـالرغم مما يتمتع بـه الموهوبون مـن استعدادات ومههارات

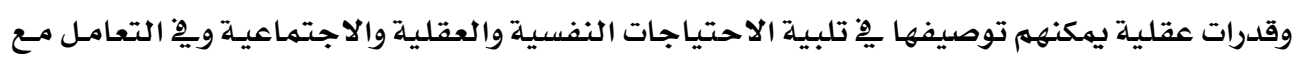

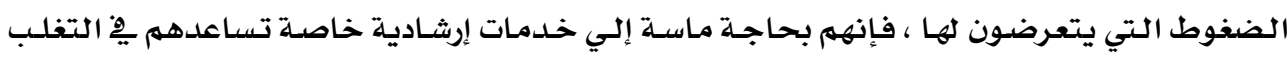

علي تلك المعوقات وتعينهم علي التوافق والتمتع بمستوي عال من الصحة النها النفسية السليمة .

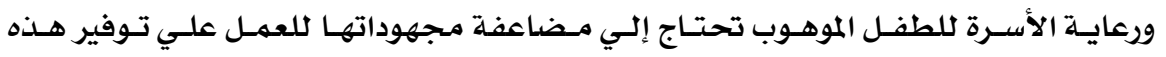

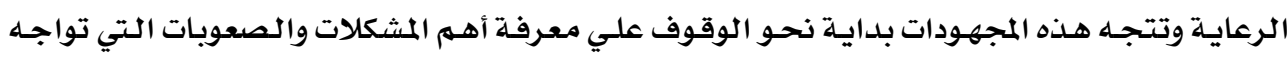

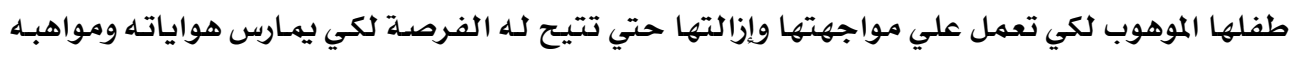

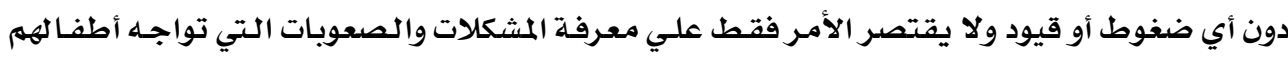

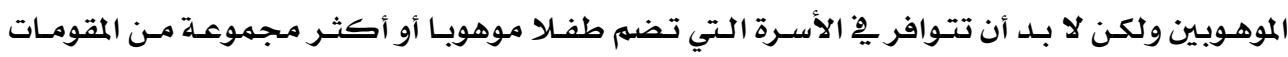

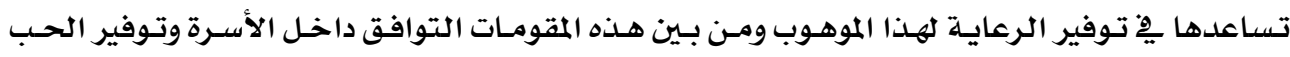

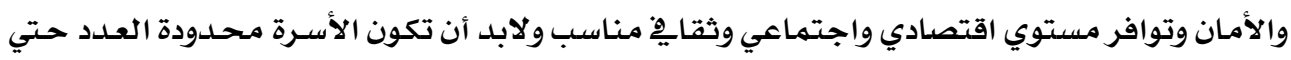

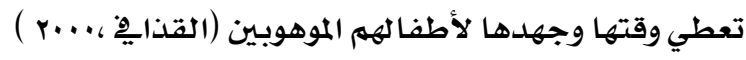

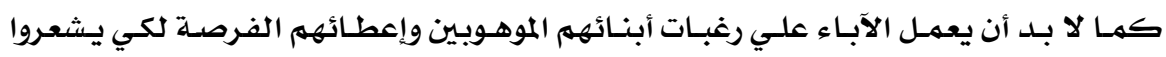

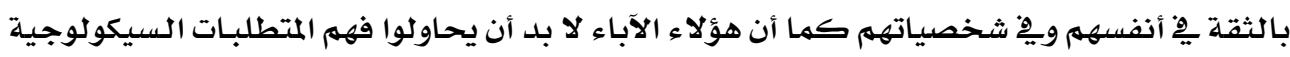

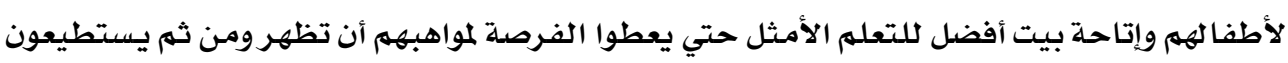

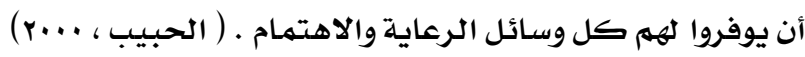

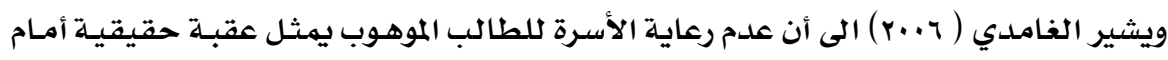

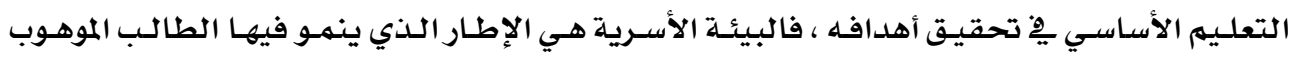

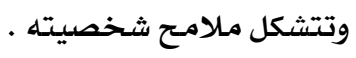

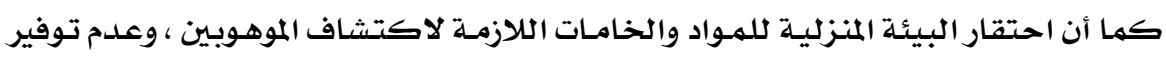

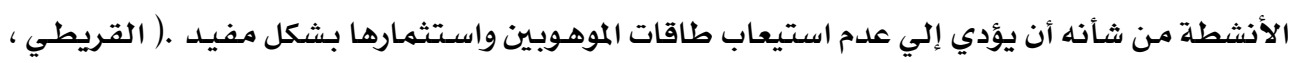

وقد بينت نتائج بعض الدراسـات أن فشل الطلبـة الموهوبين والمتفوقين عقليـا يِّ المدرسـة إنما

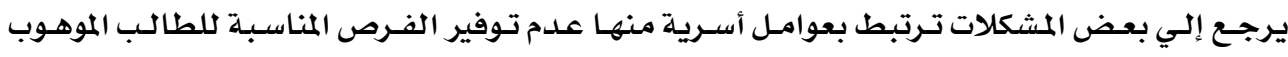

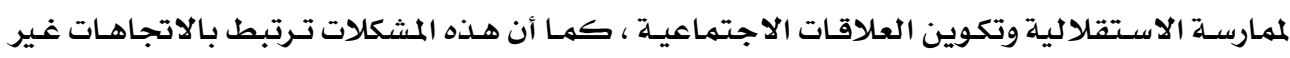

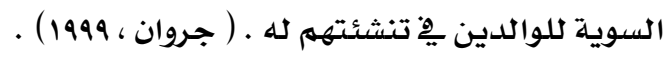

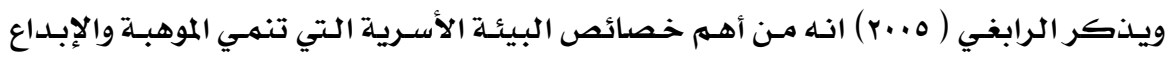

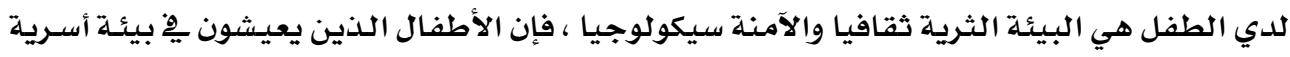

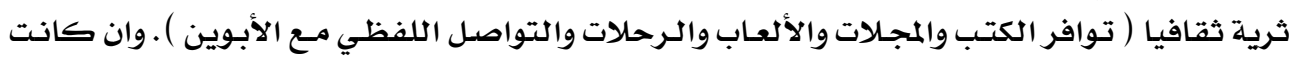

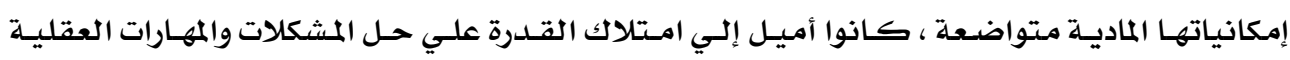




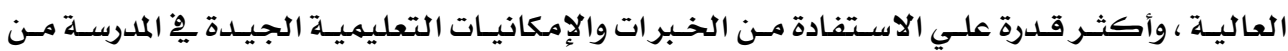

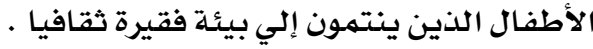

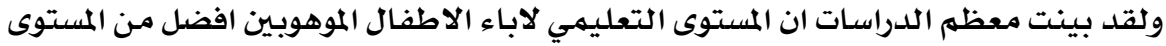

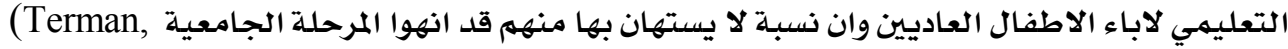

1925;Albert,1980)

كهـا اسفـرت دراسـة كل مـن تيـرمان ( Terman, 1925 ) فان تاسل باسـكا Van )

سيلفرمانوكمرني، جـروس (Gross, 1993) Tassel Baska, 1983)

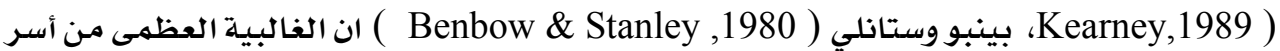
الأطفال الموهوبين بلغ عدد الأطفال فيهامن اثنين. الى ثلاثة اطفال .

وأوضحت دراسـة كل من تيرمان ( Terman, 1925 ) )، فان تاسل باسكا (Van Tassel)

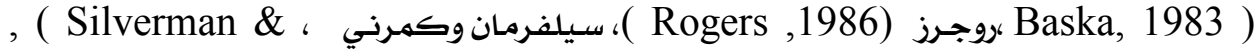

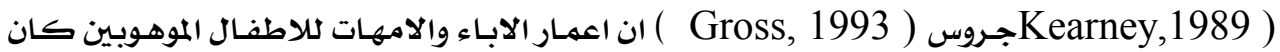
كبيرا نسبيا أي يْ أواخر العشرينات وأوائل الثلاثينيات .

ونظرا إلي وجود التفاعل اليومي مـع الأطفال ومعرفة جوانب أخري - غير أكاديميـة - فإِن

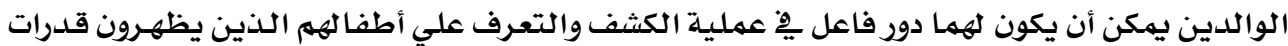

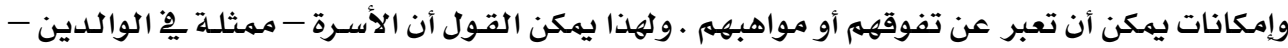

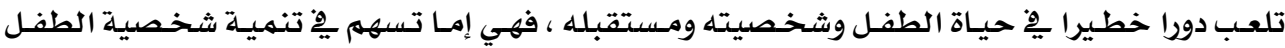

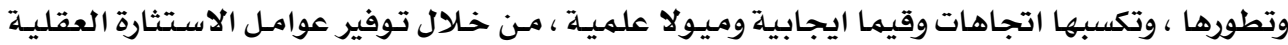

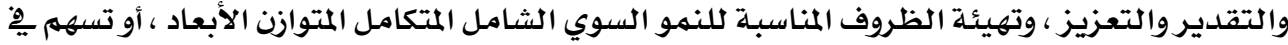

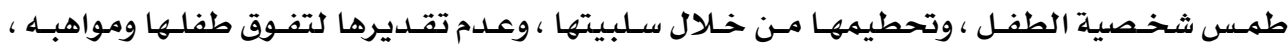

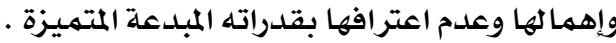

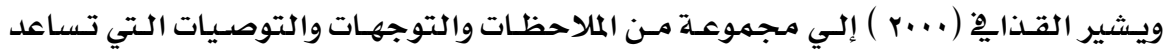

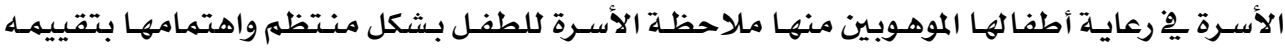

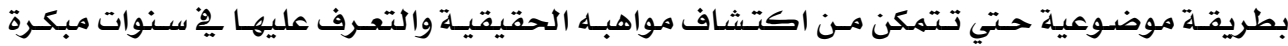

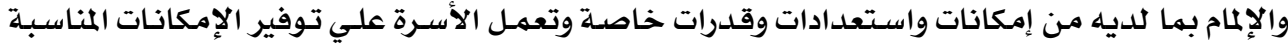

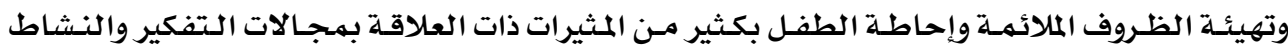

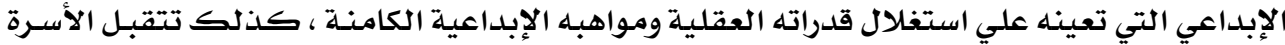

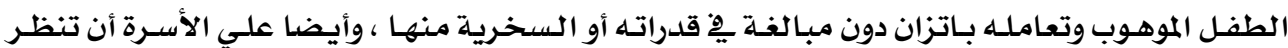

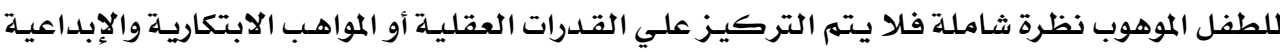

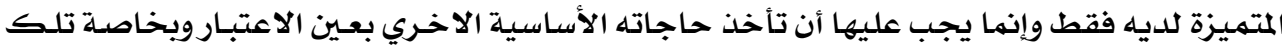

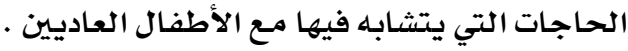


إلا أن الاسرة قد تعجز أحيانا عن القيام بدورها أمام أبنائها الموهوبين وتقديه وسائل الرعاية

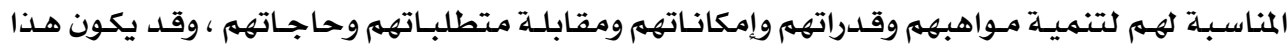

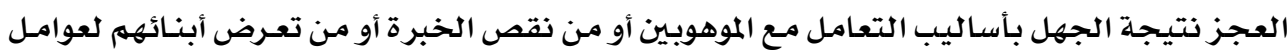

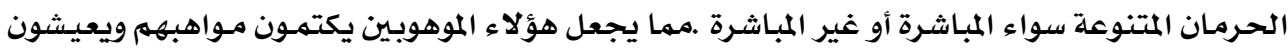

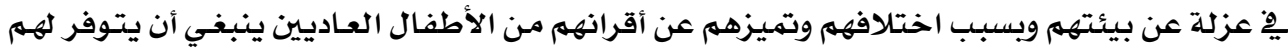
فرص مناسبة من التعليم الذي يتلاءم مـع قدراتهم واستعداداتهمه .

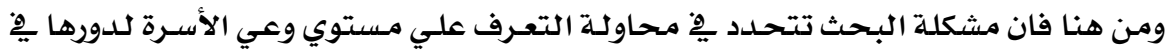

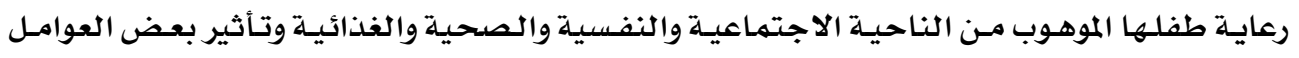

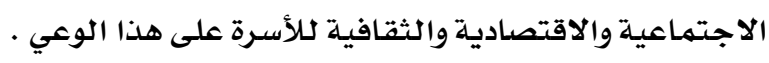
وتتمحور مشكلة البحث ِِ التساؤلات التالية :

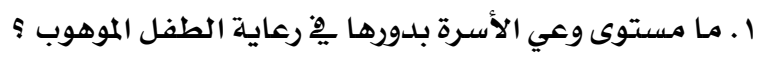

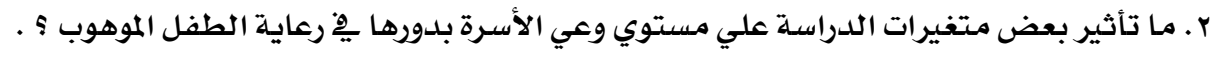

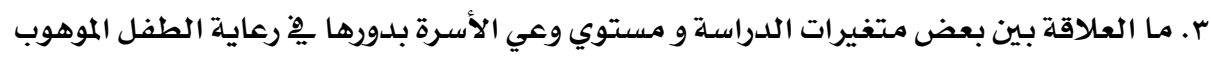

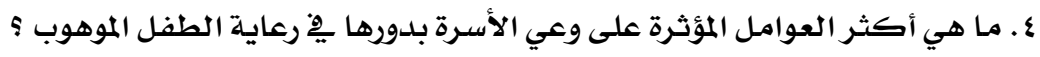

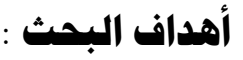

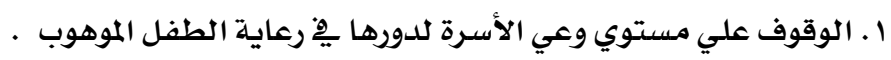

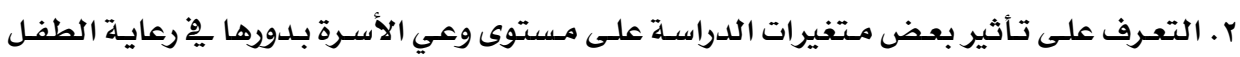

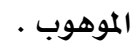
r. إيجاد العلاقة بين بعض متغيرات الدراسة ومستوي وعي الأسرة بدورها بِّ رعاية الطفل الموهوب

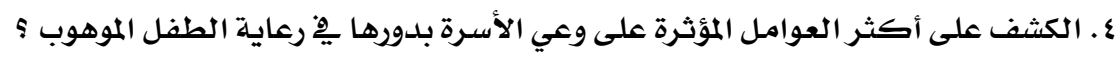

$$
\text { ا. القاء الضوء على طبيعة وخصائص الطفل الموهوب . }
$$

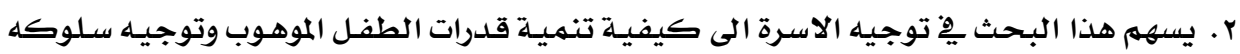

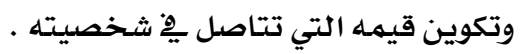

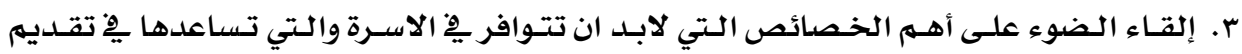

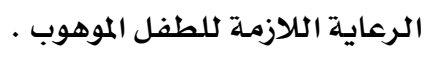

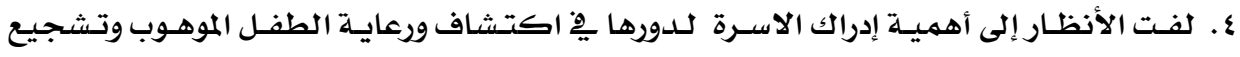

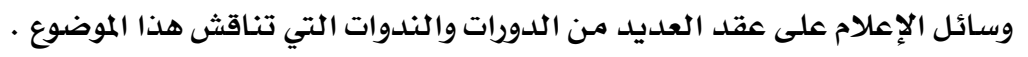

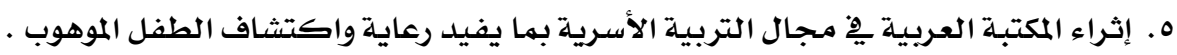


ا ـ توجد فروق ذات دلالة إحصائية بين متوسط درجات اسـر أفراد العينة ِِِّ مستوى وعيها بدورها

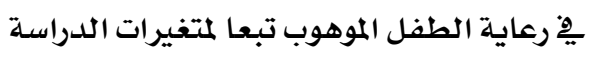

r. توجد علاقة ارتباطية بين محاور استبيان مستوى وعي الأسـرة بدورها ِِّ رعايـة الطفل الموهوب

$$
\text { ومتغيرات الدراسة }
$$

r. تختلف نسبة مشاركة العوامل المؤثرة على وعي الأسرة بدورها يِّ رعاية الطفل الموهوب .

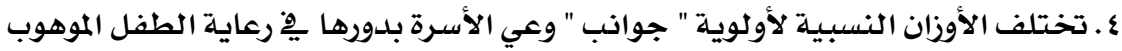

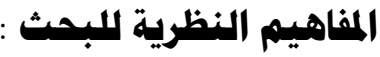

•

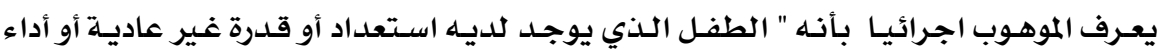

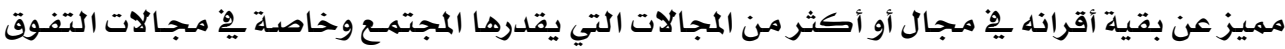

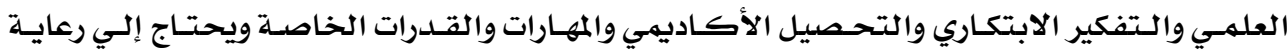

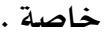

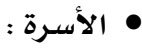

تعرف الأسرة بأنها " مجموعة من الأشخاص ارتبطوا بروابط الزواج والدم أو التبني مكونين

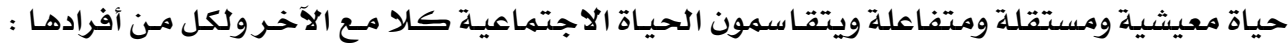

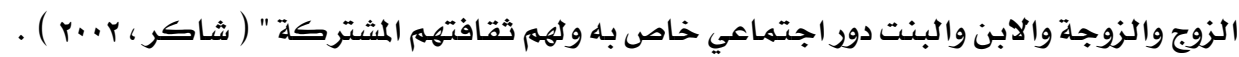
• دور الأسرة مِّْ رعاية الطفل الموهوب :

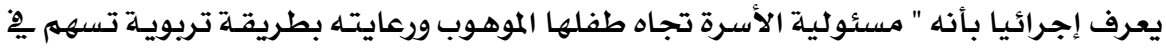

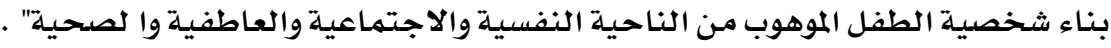

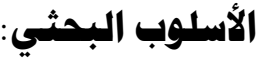

أجريت هذه الدراسة بهدف التعرف على مستوى وعي الأسرة بدورها بِّ رعاية الطفل الموهوب

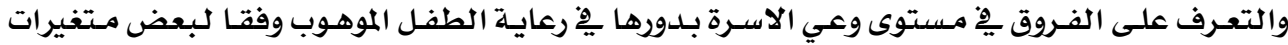

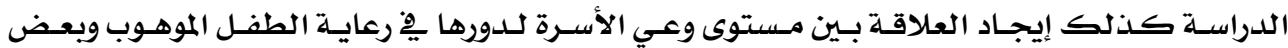

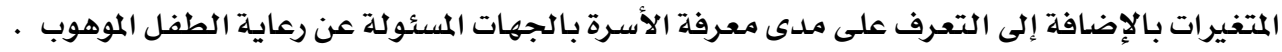
وفيما يلي عرض للإجراءات المنهجية التي اتبعتها الباحثة للوصول إلى نتائج الدراسة والتي

تتضح كما يلي : 


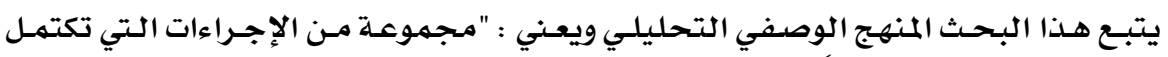

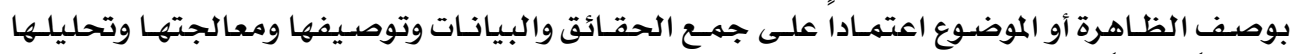

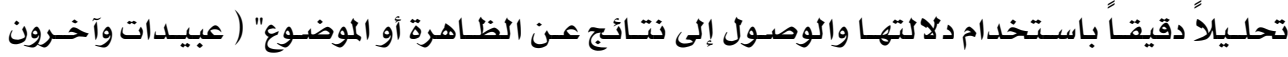

\section{ثانيًا : إعداد وبنلاء أدوات البحث}

$$
\text { تطلبت هذه الدراسة إعداد وبناء مجموعة من الأدوات : }
$$

1.استمارة البيانات العامة للأسرة .

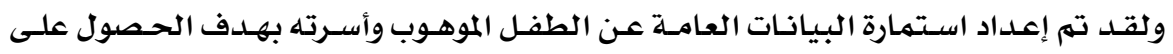

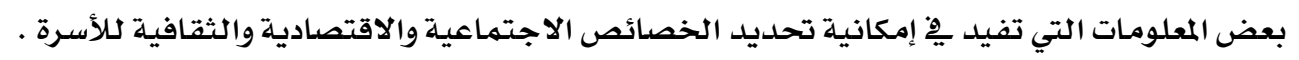

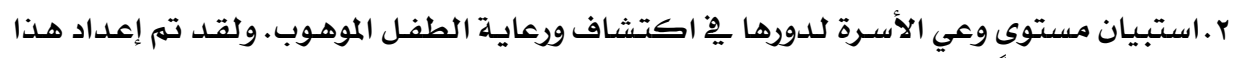

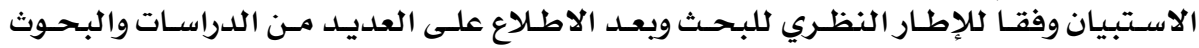

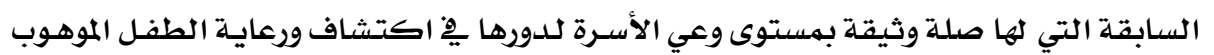

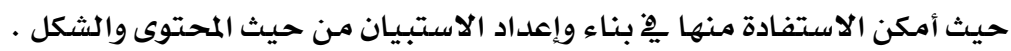

الإعداد المبلئي:

أعدت الباحثة (.ـ ) عبارة مـن عبـارات الاستبيان وقد تم توزيع العبـارات على الجوانب المراد

$$
\text { قولاً: الجها وهي :- الاجتماعي : }
$$

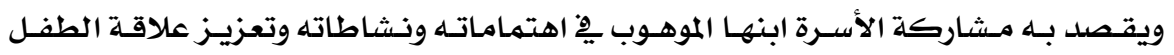

الموهوب وتفاعله مع الآخرين والحـرص على أن يتكيف مـع أشقائه ورفاقهـ بالإضـافة إلى تعـاون الأسـرة

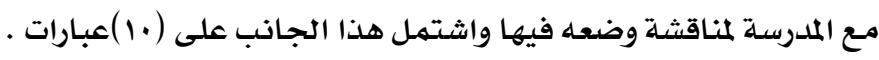

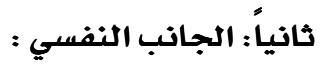

ويقصد به قدرة الأسرة على الكشف عن استعدادات طفلها الموهوب وفهمه حاجاته النفسية

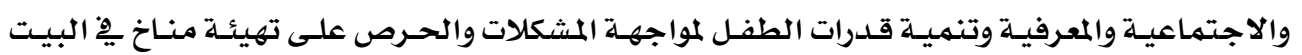

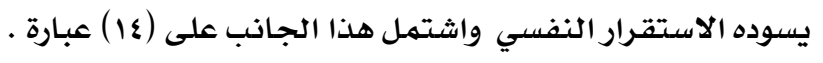

ثالثاً: الجانب العاطفي :

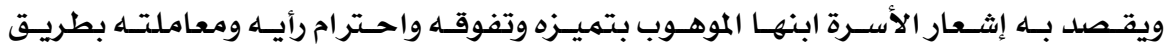

ديمقراطية وإظهار الحب غير المشروط لهه واشتمل هذا الجانب على (v)عبارات . 


$$
\text { رابعاً: الجانب الصحي : }
$$

ويقـــد بـه اهتهــام الأسـرة بـالوجبـات الغذائيـة المتوازنــة للطفـل والكـشف الـــوري للطفـل

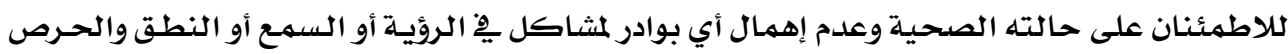

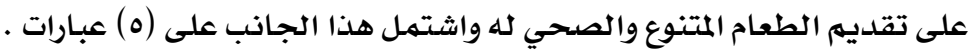
خامساً: الجانب الثقاهِ : ويقصد بـه اهتمام الأسرة بتتظيهم وقت فراغه وحسن استثماره وتزويده بالمعلومـات والأنشطة

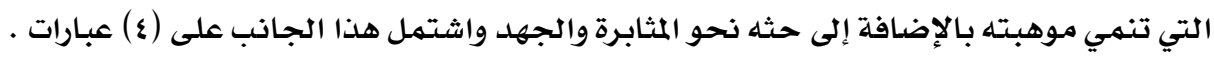

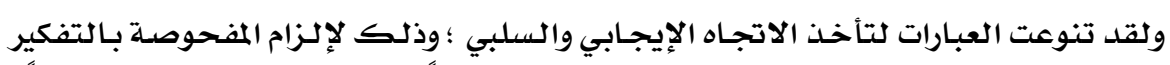

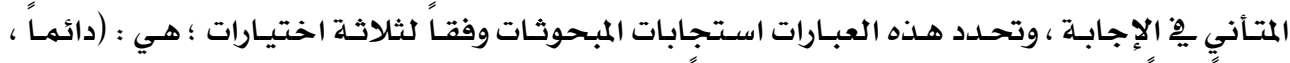

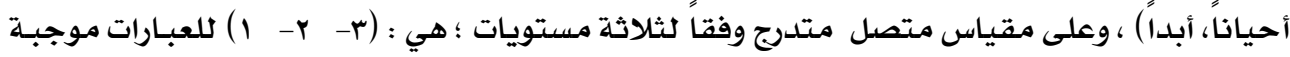

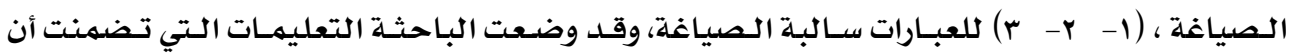

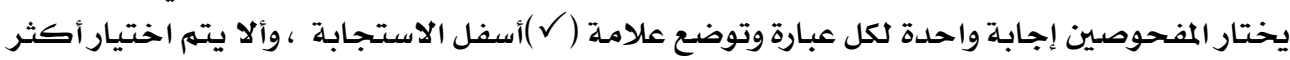

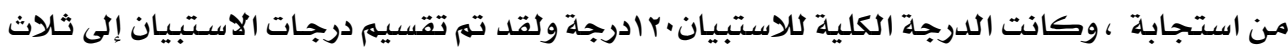

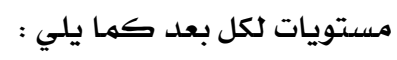

$$
\begin{aligned}
& \text { • مستوى منخفض : للحاصلين على أقل من ( • ) ) }
\end{aligned}
$$

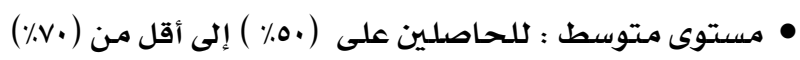

$$
\begin{aligned}
& \text { • مستوى مرتفع : للحاصلين على ( • ٪ ) فأكثر. } \\
& \text { تقنيز الأداة : ( يقصد به صدق وثبات الاستبيان ) }
\end{aligned}
$$

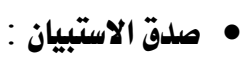

$$
\begin{aligned}
& \text { يقصد بـه قدرة الاستبيان على قياس ما وضع لقياسـه . }
\end{aligned}
$$

الصلدق باستخدام الاتساق الداخلي بين الدرجة الكلية لكل محوروالدرجة الكلية للاستبيان :

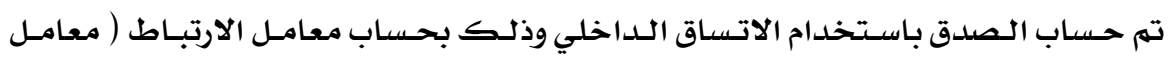

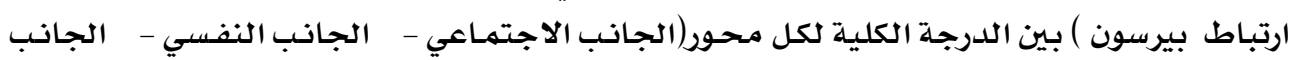

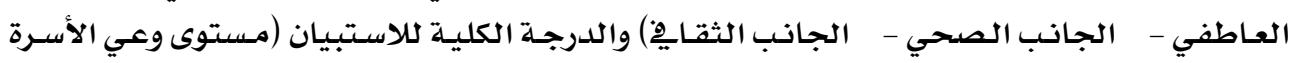

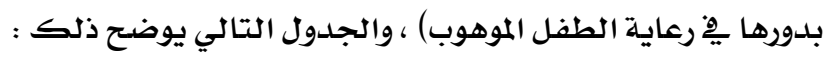


جدول ( 1 ) قيم معاملات الارتباط بين درجة كل محورودرجة استبيان

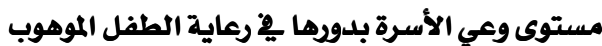

\begin{tabular}{|c|c|c|}
\hline الدلادلة & الارتباط & محاور الاستبيان \\
\hline$\cdot, \cdot 1$ & $\cdot, \wedge \wedge 1$ & المحور الأول : الجانب الاجتماعي \\
\hline$\cdot, \cdot 1$ & •, vor & المحور الثاني : الجـانب النفسي \\
\hline$\cdot, \cdot 1$ & $\cdot 9 Y 1$ & المحور الثالث : الجانب العاطفي \\
\hline$\cdot, \cdot 1$ & $\cdot, \wedge \varepsilon \uparrow$ & المححور الرابـع: الجـانب الصحي \\
\hline$\cdot, \cdot 1$ & - qu\& & المحور الخامس : الجانب الثقايِ \\
\hline
\end{tabular}

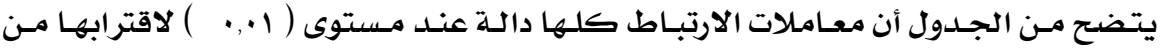
الواحد الصديح مها يلدل على صدل وتجـانس مححاور الاستبـيان .

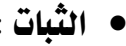

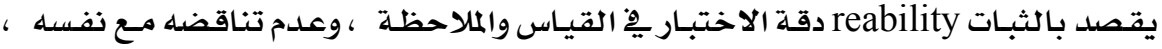

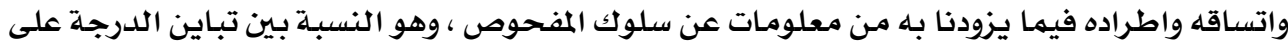

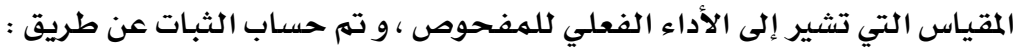

Alpha Cronbach - معامل الفا كرونباخ

Split-half - بريقة التجزئة النصفية

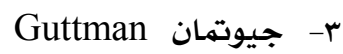

جدول ( r ) قيم معامل الثبات لمحاور استبيان مستوى وعي الأسرة بدورها يِّ رعاية الطفل الموهوب

\begin{tabular}{|c|c|c|c|}
\hline جيوتمان & التجرزئة النصفية & معامـل الفـا & المحاور \\
\hline$\cdot, \vee \wedge 9$ & $\cdot, \Lambda Y V-\cdot, V Y I$ & $\cdot, \wedge \cdot 7$ & المحرور الأول : الجـانب الاجتهـاعي \\
\hline$\cdot, \Lambda \cdot r$ & $\cdot, \wedge 01-\cdot, V \leqslant 0$ & - & المحور الثانى : الجانب النفسى \\
\hline •,Arr & $\cdot, \wedge T Y-\cdot$, VOV & $\cdot, \wedge \mu \wedge$ & المحور الثالث : الجانب العاطفي \\
\hline$\cdot 9 \cdot 7$ & $\cdot, 9 \curlyvee \varepsilon-\cdot, \wedge \uparrow$. & $\cdot, 91 \mathrm{~V}$ & المحور الرابع: الجـانب الصحي \\
\hline$\cdot, \wedge \leqslant 0$ & $\cdot, \Lambda \vee \wedge-\cdot, \mathrm{VAr}$ & $\cdot, \wedge 09$ & المحور الخامس : الجانب الثقايخ \\
\hline$\cdot, \Lambda \wedge \vee$ & $\cdot, 9 \cdot 9-\cdot, \wedge r \varepsilon$ & $\cdot, \wedge 99$ & ثبـات الاستبيـان ككل \\
\hline
\end{tabular}

يتضـح من الجدول السـابق أن جميع قيم معاملات الثبات : معامل الفـا ، التجزئــة النصفية ،

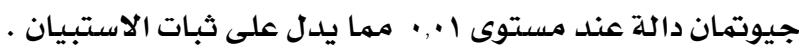


تم تجميـع أدوات البحث ِِْ شكل استمارة استقصـاء واحسدة حتى يسهل توزيعها وتطبيقيها

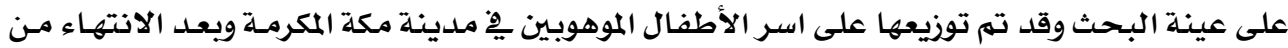

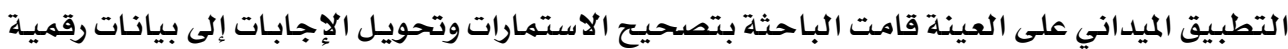

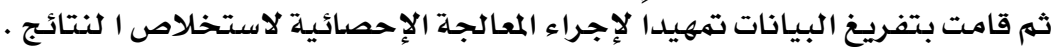

\section{رابعا : إجراء التحليلات الإحصائية}

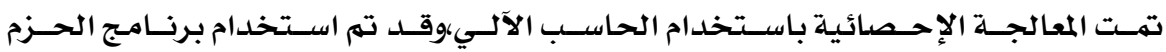

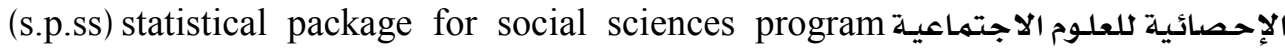
وذلك لإجراء الأسـاليب الإحصائية على متغيرات الدراسة للكشف عن نوع العلاقة بـين هـذه المتتغيرات وللتحقق من صحمة الفروض •

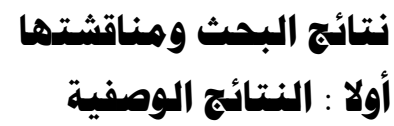
عينة البحث :

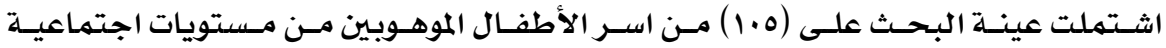

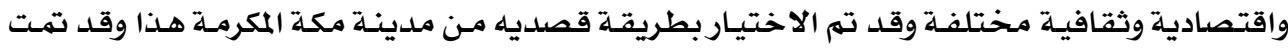

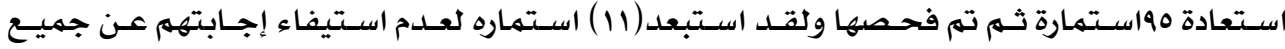

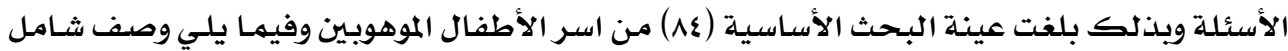

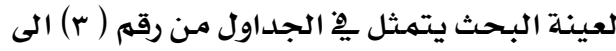

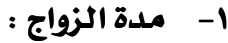

جدول ( r ) توزيع اسر عينة البحث تبعا لمتغير مدة الزواج

\begin{tabular}{|c|c|c|}
\hline 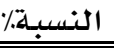 & العدد العد & مدة الزواج \\
\hline$\%$ Y & rr & اقل مـن ه سنوات \\
\hline$\% 1 V, 9$ & 10 & من ه سنوات إلى اقل من · ا سنوات \\
\hline$\% r \cdot, q$ & rT & مـن · ا سنـوات إلىي اقل مـن 10 سنــة \\
\hline$\%$ Yo & YI & من 10 سنـة فأكثر \\
\hline$\% 1 \ldots$ & $\Lambda \varepsilon$ & المجهموع \\
\hline
\end{tabular}




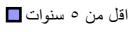

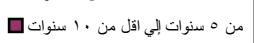

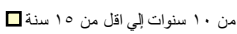

من 10 سنة فأكثر من سن

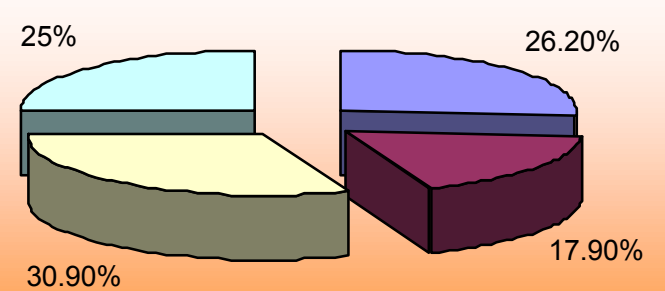

شكل ( 1 ) يوضح توزيع اسر عينة البحث تبعا لمتغير مدة الزواج

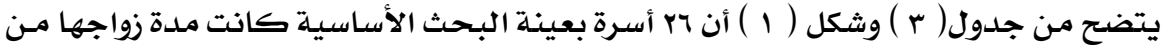

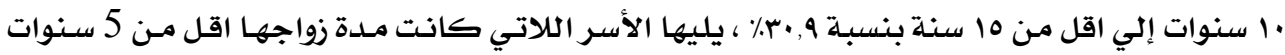

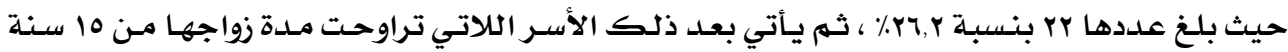

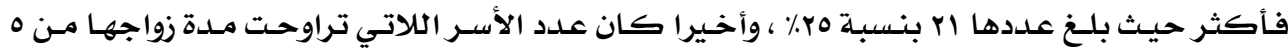
سنوات إلي اقل من • ا سنوات "10" بنسبـة IV,9٪ . r

جدول (ع) توزيع الوالدين بعينة البحث تبعا ملتغير العمر

\begin{tabular}{|c|c|c|c|c|}
\hline \multicolumn{2}{|c|}{ الأم } & \multicolumn{2}{|c|}{ الأب } & \multirow{2}{*}{ عمـر الوالدين } \\
\hline النسبـة:٪ & العدد الع & |النسبـة:| & العدد & \\
\hline$\% 1 \varepsilon, r$ & ir & $\% 1 \cdot, V$ & 9 & مـن ·r سنــة إلى اقل مـن·r سنـة \\
\hline$\%$ \%૫, & rq & $\%$ Y I, $\varepsilon$ & 11 & مـن·r سـنة إلى اقل مـن ·ع سنـة \\
\hline$\%$ \% r,r & 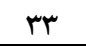 & $\% 7 \vee, 9$ & ov & من ، ع سنـه فأكثر \\
\hline$\% 1 \ldots$ & $\Lambda \varepsilon$ & $\% 1 \cdots$ & $\Lambda \varepsilon$ & المجهوع \\
\hline
\end{tabular}




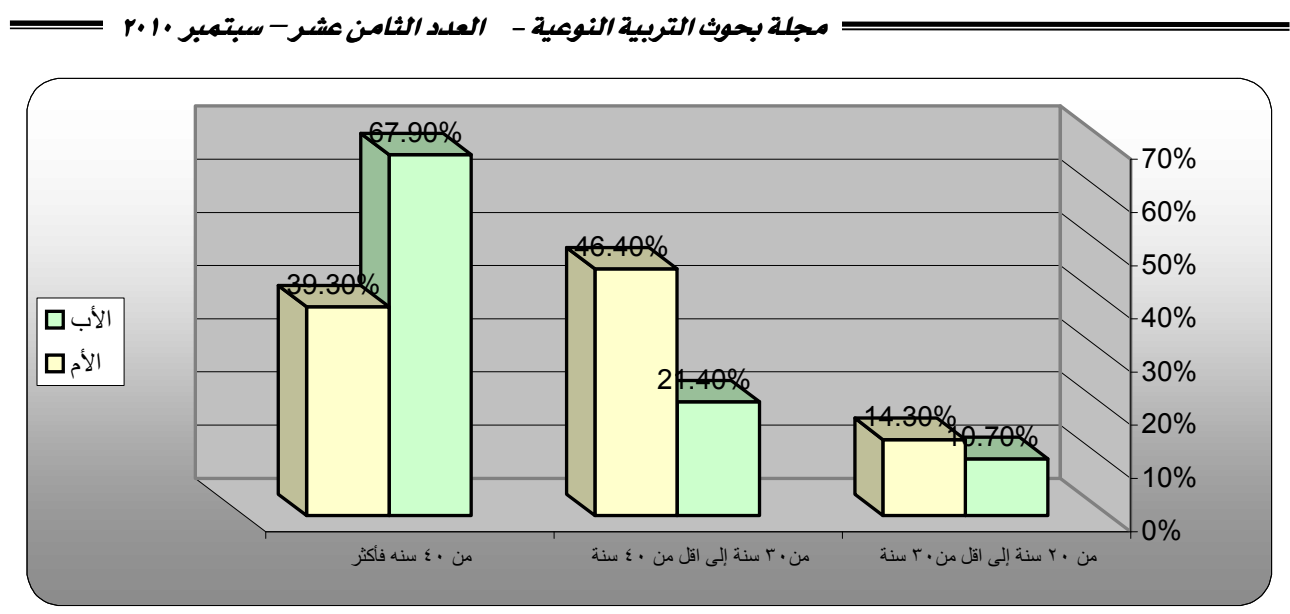

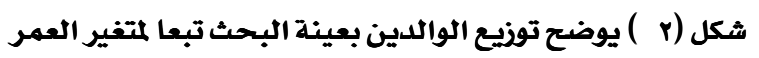

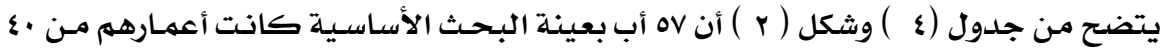

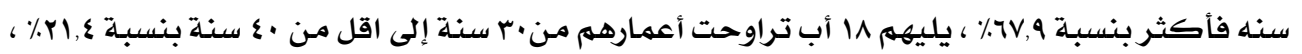

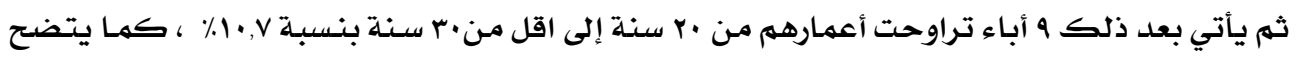

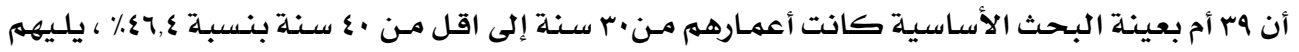

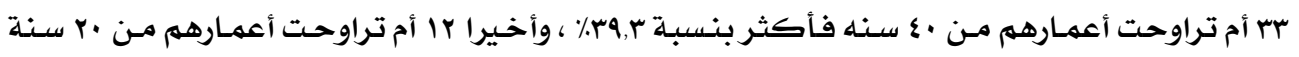

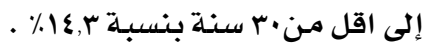

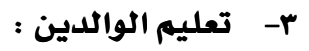

جدول ( ه ) توزيع الوالدين بعينة البحث تبعا لمتغير المستوى التعليمي

\begin{tabular}{|c|c|c|c|c|}
\hline \multicolumn{2}{|c|}{ الأم } & \multicolumn{2}{|c|}{ الأب } & \multirow{2}{*}{ مستوى تعليهم الوالدين } \\
\hline النسبــة/٪ & العدد & |النسبـة/٪ & العدد العد & \\
\hline$\%, Y, \varepsilon$ & 11 & $\% 1 \cdot, V$ & 9 & يقرا ويكتب \\
\hline$\% 1 \varepsilon, r$ & ir & $\% 1 \cdot, V$ & 9 & الشهادة الابتدائية \\
\hline$\% 17, V$ & $1 \varepsilon$ & $\% 1 \vee, 9$ & 10 & الشهادة المتوسطة \\
\hline 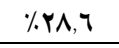 & $r \varepsilon$ & 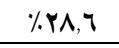 & 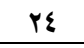 & الشهادة الثانوية \\
\hline$\% 17, V$ & $1 \varepsilon$ & $\%$ Yr,T & 19 & الشهادة الجـامعيـة \\
\hline$\%, r, r$ & $r$ & $\%, 9,0$ & $\wedge$ & ماجستير - دكتوراه \\
\hline$\% 1 \ldots$ & $\wedge \varepsilon$ & $\% 1 \ldots$ & $\wedge \varepsilon$ & المجموع \\
\hline
\end{tabular}




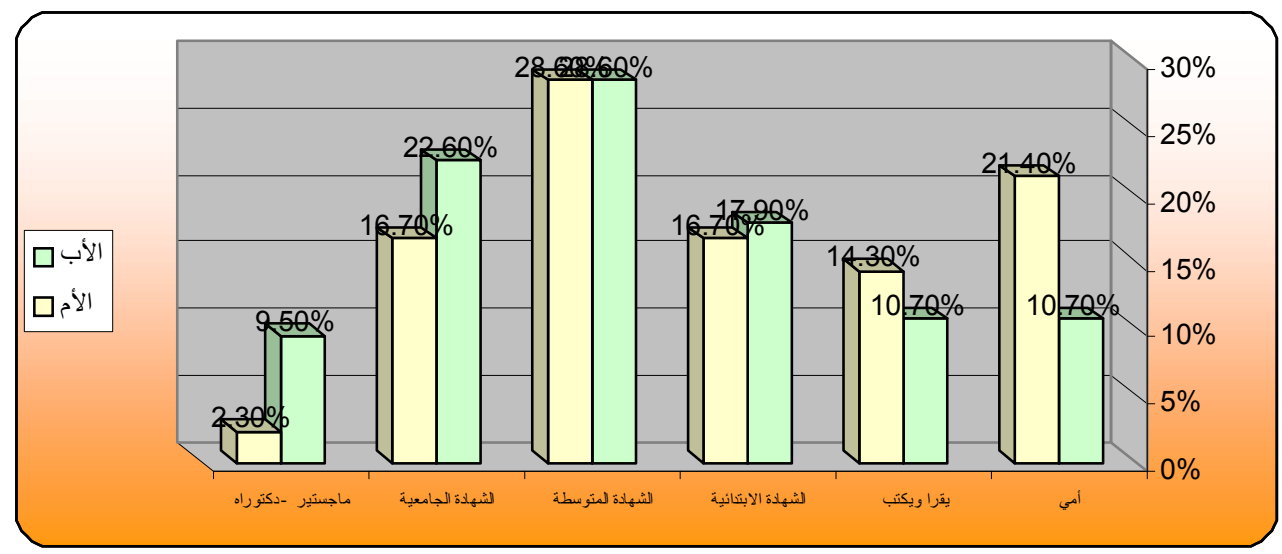

شكل ( r ) يوضح توزيع الوالدين بعينة البحث تبعا لمتغير المستوى التعليهي

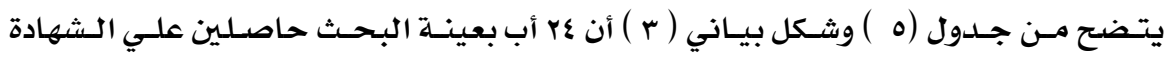

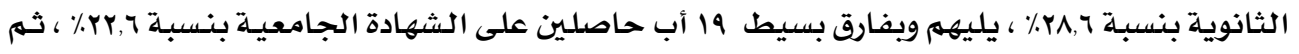

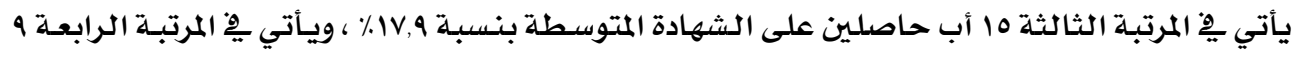

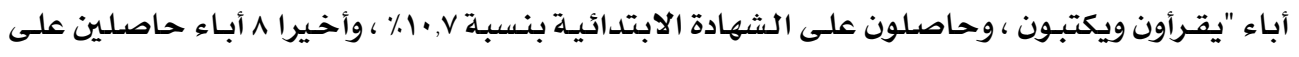

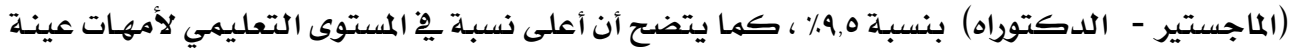

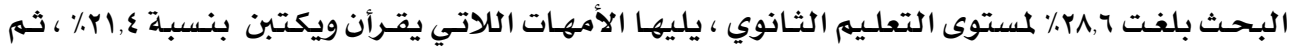

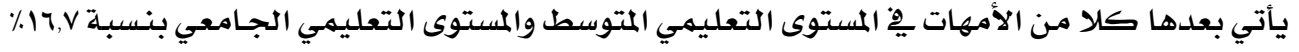

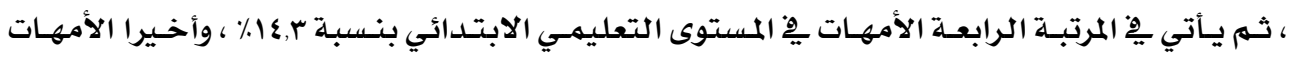

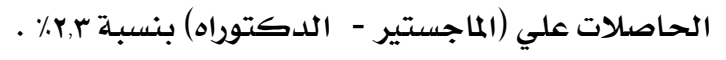

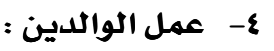
جدول ( T ) توزيـع الوالدين بعينة البحث تبعا لمتغير العمل

\begin{tabular}{|c|c|c|c|c|}
\hline \multicolumn{2}{|c|}{ الأم } & \multicolumn{2}{|c|}{ الأب } & \multirow{2}{*}{ عمل الوالدين } \\
\hline النسبـة_/ & العدد & النسبــة/٪ & العدد & \\
\hline$\% 17, V$ & $1 \varepsilon$ & $\% 1 \ldots$ & $\Lambda \varepsilon$ & نعمى \\
\hline$\%$ \% r,r & v. & - & - & ע \\
\hline$\% 1 \ldots$ & $\Lambda \varepsilon$ & $\% 1 \ldots$ & $\Lambda \varepsilon$ & المجموع \\
\hline
\end{tabular}




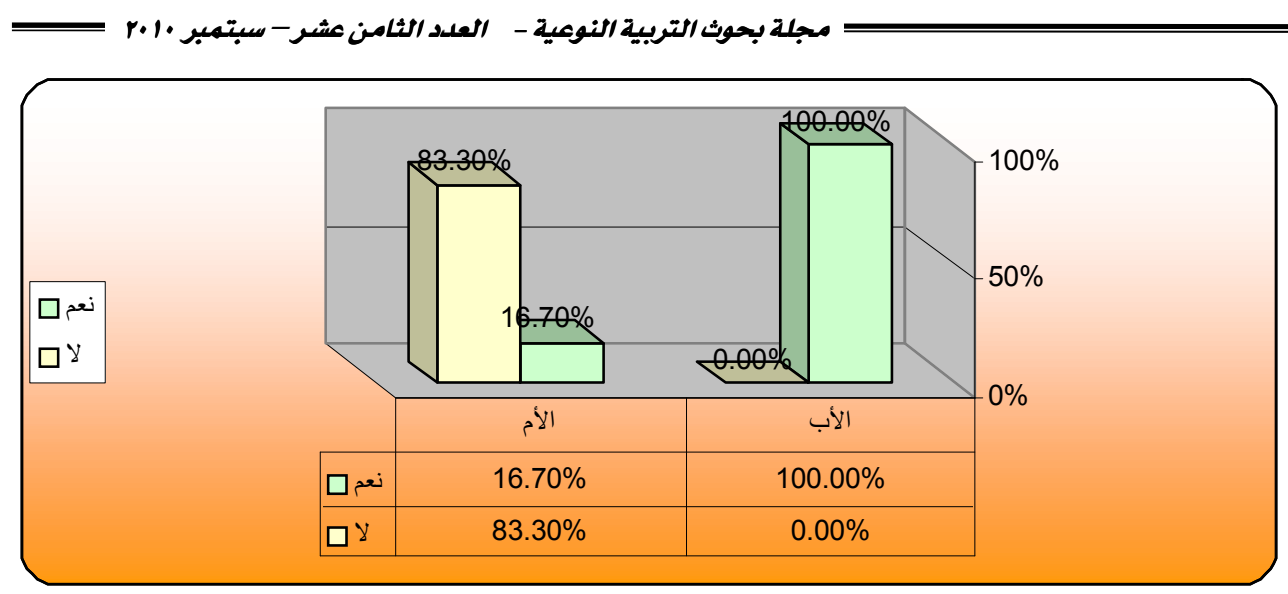

شكل ( ع ) يوضتح توزيـع الوالدين بعينة البحث تبعا لمتغير العمل

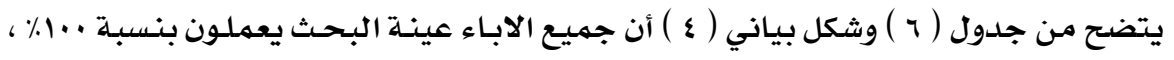

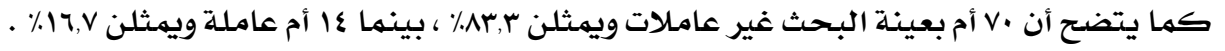

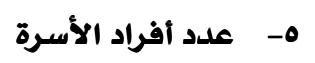

جدول ( ) توزيـع أسـر عينة البحث تبعاً لعدد أفرادها

\begin{tabular}{|c|c|c|}
\hline النسبـة/. & العلدد & عدد أفراد الأسـرة \\
\hline$\% 19$ & 17 & اقل مـن ع أفراد \\
\hline \%rr,r & YM & مـن ع أفراد إلى V أفراد \\
\hline$\% \varepsilon \vee, 7$ & $\varepsilon$. & ^ أفراد فأكثر \\
\hline$\% 1 \ldots$ & $\Lambda \varepsilon$ & المجمهوع \\
\hline
\end{tabular}

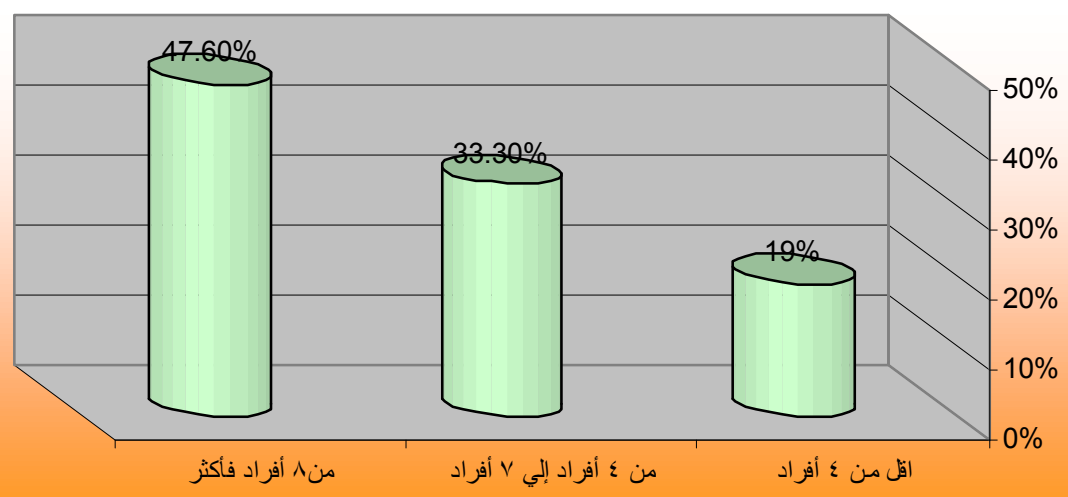

شكل ( 0 ) يوضع توزيع أسر عينة البحث تبعاً لعدد أفرادها 


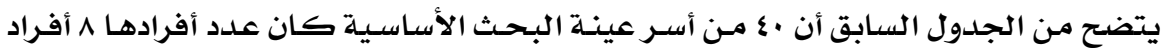

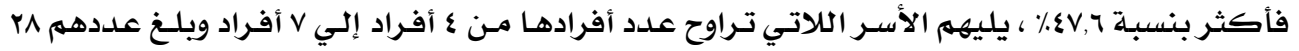

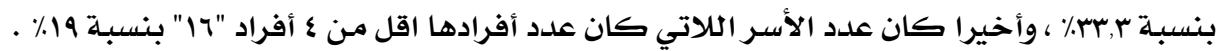
ج- الدخل الشهري لكلأسرة :

جدول ( 1 ) توزيع أسر عينة البحث وفقا لفئات الدخل المختلفة

\begin{tabular}{|c|c|c|}
\hline |النسبـة// & العدد ال العد & الدخل الشهري لـلأسرة \\
\hline$\% 1 \varepsilon, r$ & ir & 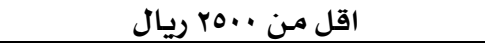 \\
\hline$\%$ YV, $\varepsilon$ & $r r$ & 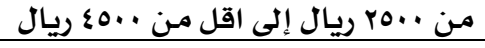 \\
\hline$\%$ Y O & YI & 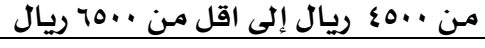 \\
\hline$\% 1 r, 1$ & 11 & 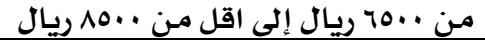 \\
\hline$\%, 0,9$ & 0 & 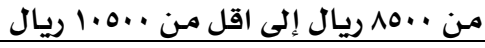 \\
\hline$\% 1 \varepsilon, r$ & ir & مـن ·. • 1 ريال فأكثر \\
\hline$\% 1 \cdots$ & $\Lambda \varepsilon$ & المجموع \\
\hline
\end{tabular}

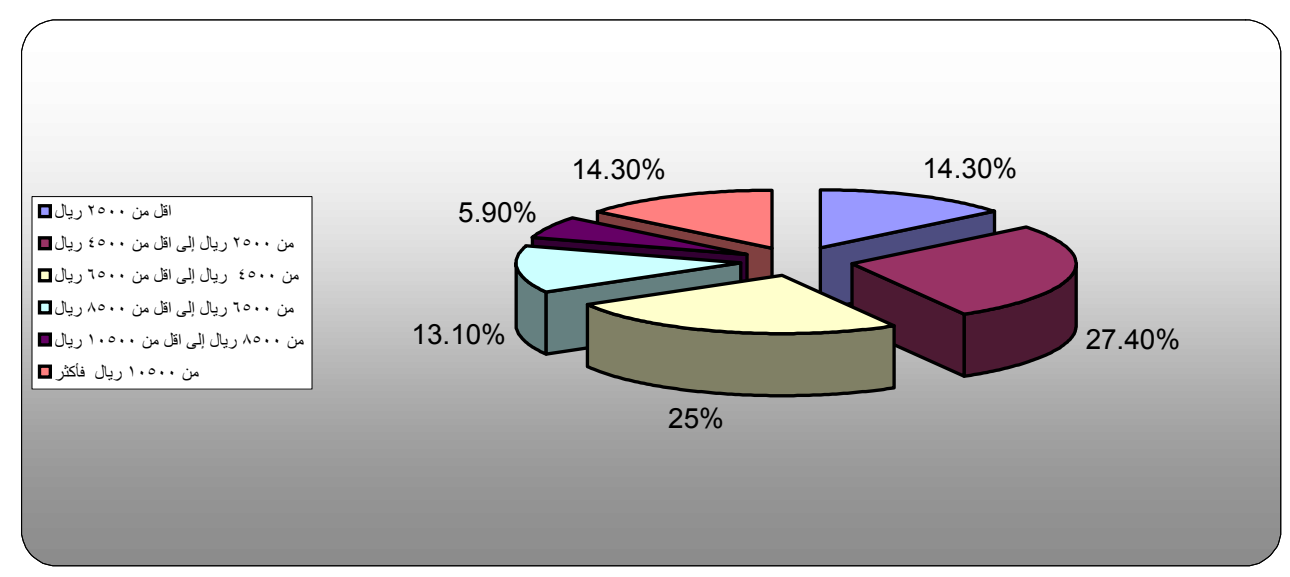

شكل ( ا ) يوضح توزيع أسر عينة البحث وفقا لفئات الدخل المختلفة

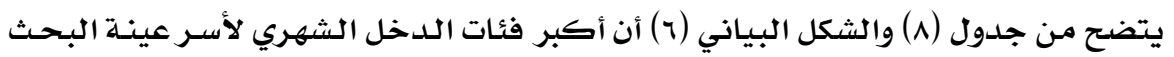

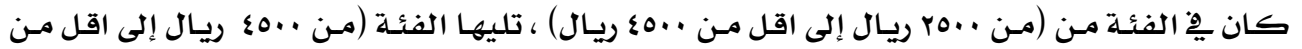

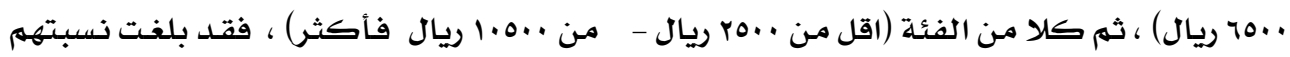

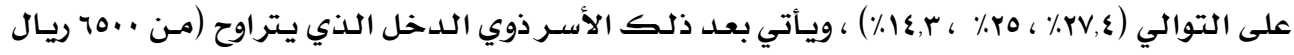

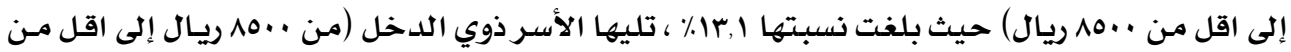

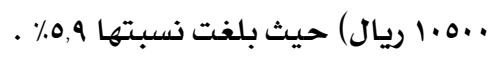


جدول (9) عمر الأبناء الذكوروالإناث بأسر عينة البحث

\begin{tabular}{|c|c|c|c|c|}
\hline \multicolumn{2}{|c|}{ 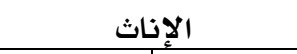 } & \multicolumn{2}{|c|}{ الذكور } & \multirow{2}{*}{ عمر الأبناء } \\
\hline النسبـة/٪ & العدد ال العد & |النسبـة/٪ & 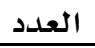 & \\
\hline$\%, 0$ & 11 & $\% 1 \cdot, r$ & 10 & اقل من سنـة \\
\hline$\% 11, \wedge$ & ro & $\% 1 \varepsilon, r$ & rl & من سنـه إلى اقل مـن ع سنـوات \\
\hline$\%$ Y, 0 & 07 & $\% r r, 1$ & $r \varepsilon$ & مـن ع سنوات إلى اقل من ^ سنوات \\
\hline$\%$ & TV & $\%$ rV, 9 & \&1 & من ^ سنوات إلى اقل من Y I سنـة \\
\hline$\%, r, r$ & «0 & $\%$ \%, 0 & ד & من ب ا سنـة فأكثر \\
\hline$\% 1 \ldots$ & rII & $\% 1 \cdots$ & $1 \leqslant V$ & المجمهوع \\
\hline
\end{tabular}

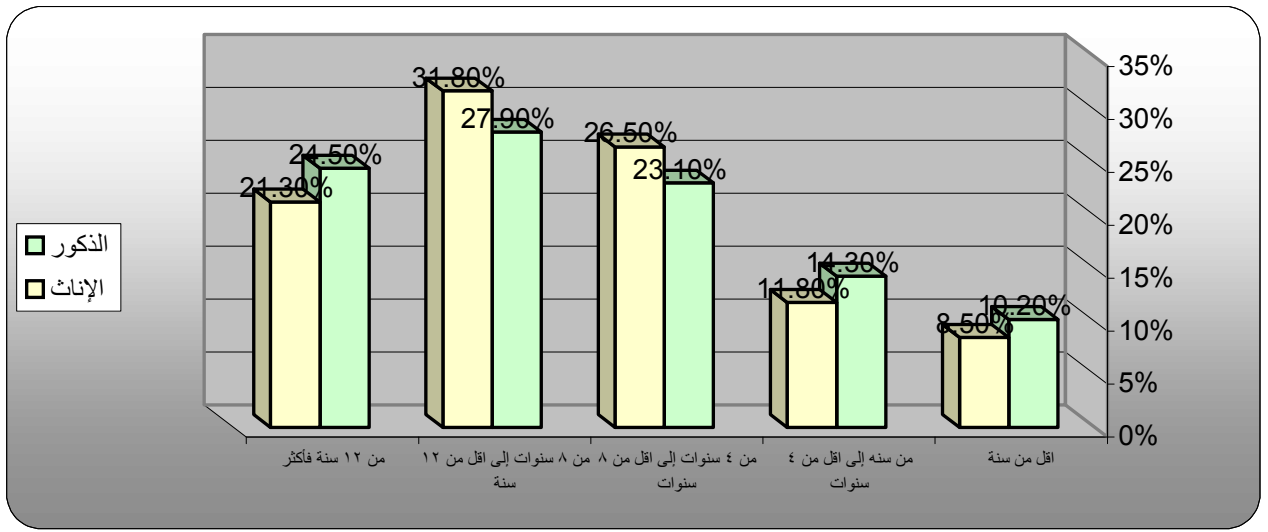

شكل ( v ) يوضـح عمر الأبناء الذكور والإناث بأسر عينة البحث

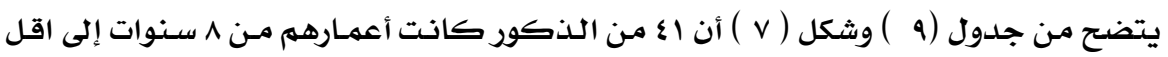

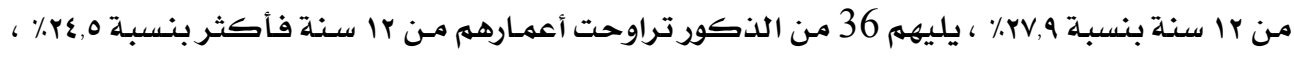

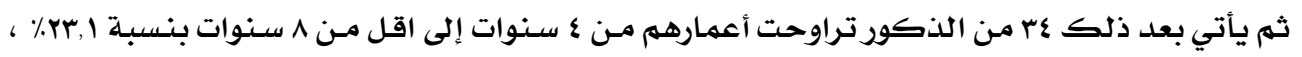

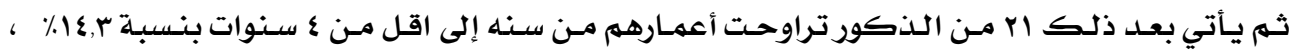

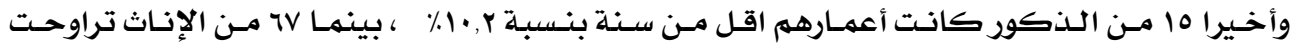

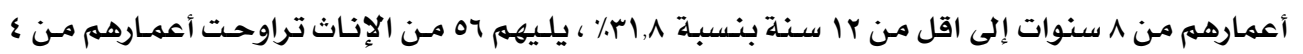

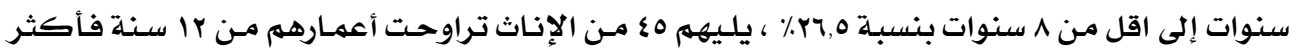

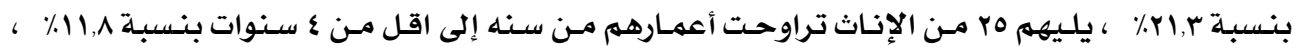

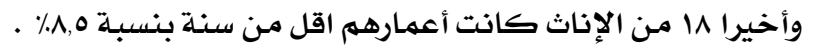


1- الأقارب اللذين يعيشون مـ الأسرة بصفة دائمة :

جدول ( 1 ) الأقارب اللذين يعيشون مع اسر عينة البحث بصفة دائمة

\begin{tabular}{|c|c|c|}
\hline | النسبية:| & العدد اد & هل هناك أقارب يعيشون مـع الأسـرة بصفة دائمـة \\
\hline$\%, 0$ & $\wedge$ & نعمى \\
\hline$\% \cdot 9 \cdot, 0$ & vч & ע \\
\hline$\% 1 \ldots$ & $\Lambda \varepsilon$ & المجهموع \\
\hline
\end{tabular}

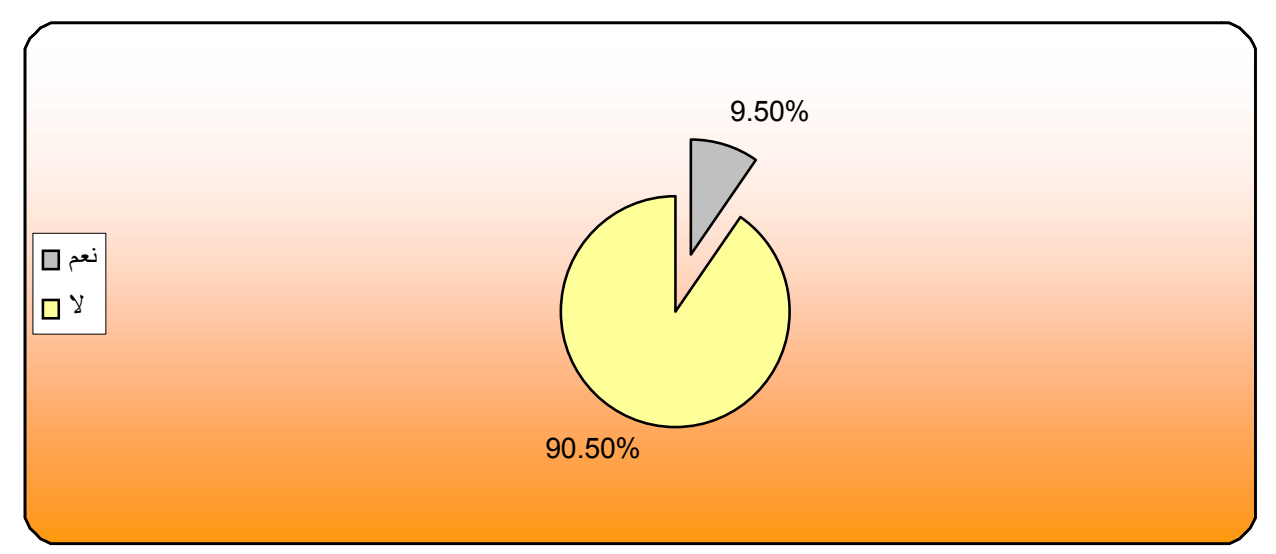

شكل (ه ) يوضح الأقارب اللذين يعيشون مع اسر عينة البحث بصفة دائمة

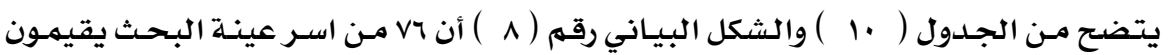

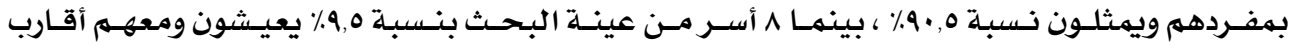

مقيم-ين بصفة دائمة .

9- صلة القرابة للافراد المقيمـين مـع الاسرة للطفل

جدول ( 11 ) صلة القرابة كلافراد المقيمين مع الاسرة للطفل

\begin{tabular}{|c|c|c|}
\hline النسبـة/٪ & 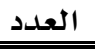 & صلـة القرابـة للافراد المقيمـين مـع الاسـرة للطفل \\
\hline$\%$ rv, 0 & r & 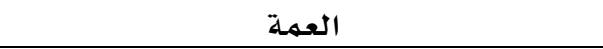 \\
\hline$\%$ rV,, 0 & r & 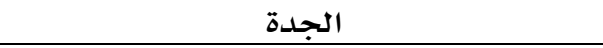 \\
\hline$\% 1 r, 0$ & 1 & 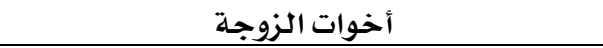 \\
\hline$\% 1 r, 0$ & 1 & 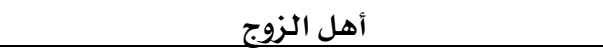 \\
\hline$\% 1 \cdots$ & $\wedge$ & المجموع \\
\hline
\end{tabular}




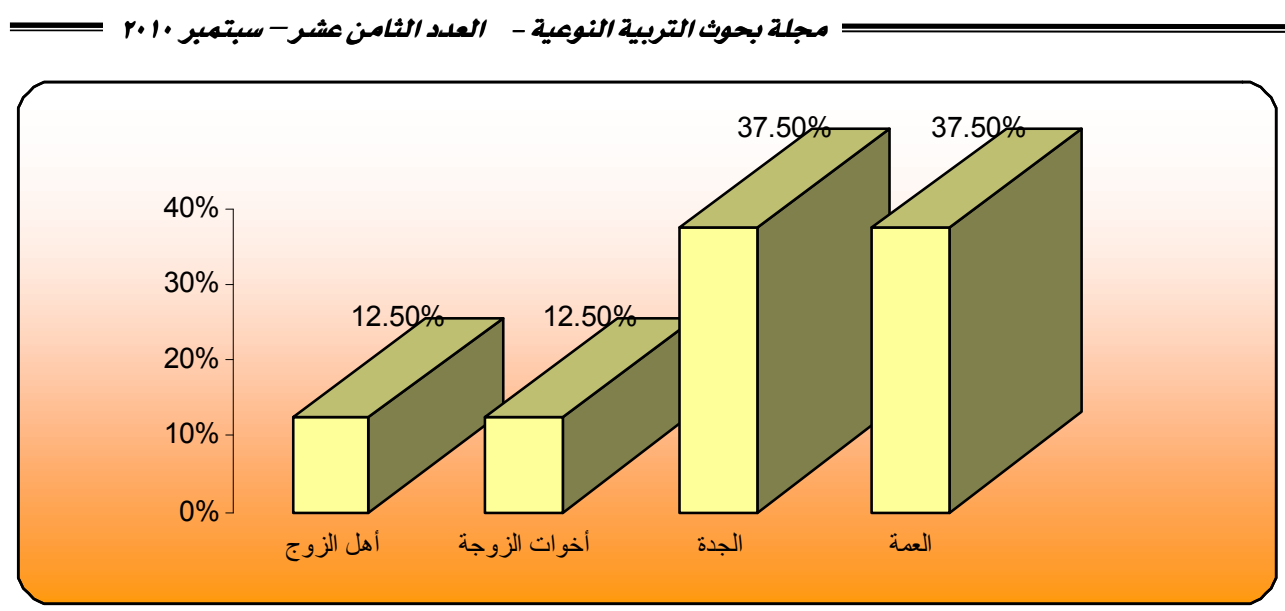

\section{شكل (9 ) يوضح صلة القرابة للطفل}

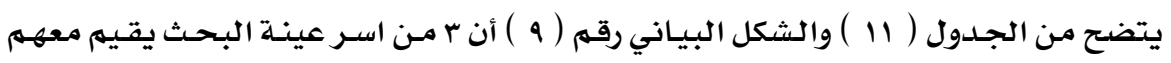

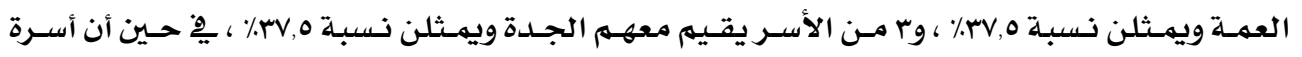

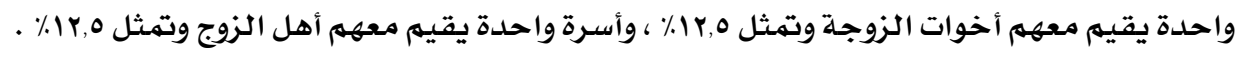

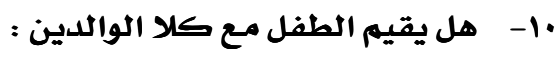
جدول ( r ) اقامة الطفل مع كلا الوالين

\begin{tabular}{|c|c|c|}
\hline النسبــة/. & العلدد & هل يقيهم الطفل مـع كال الوالدين \\
\hline$\% 9 r, 9$ & vA & نعم \\
\hline$\% \vee, 1$ & 7 & ע \\
\hline$\% 1 \ldots$ & $\Lambda \varepsilon$ & المحموع \\
\hline
\end{tabular}

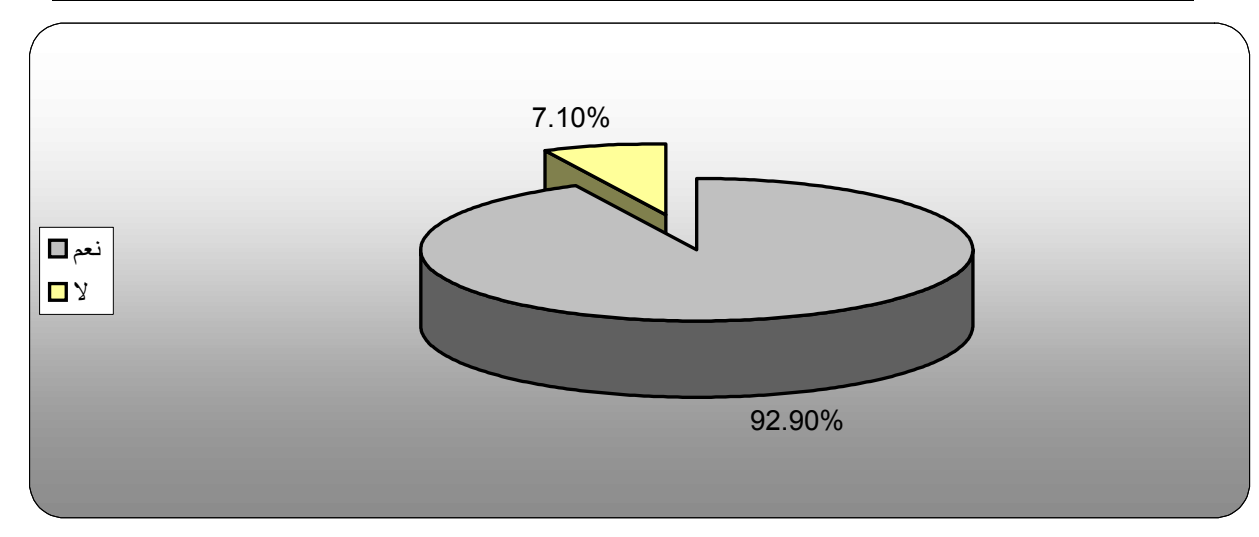

شكل ( . 1 ) يوضح اقامـة الطفل مـع كلا الوالين 


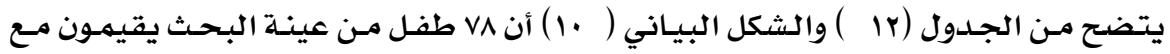

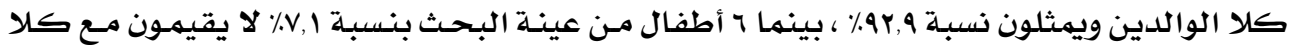

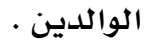

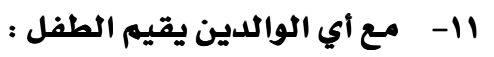

جدول ( r ا ) مع أي الوالدين يقيم الطفل

\begin{tabular}{|c|c|c|}
\hline | النسبـة| & 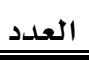 & مـع أي الوالدين يـيـم الطفل \\
\hline$\%$ & $r$ & مـع الأب \\
\hline$\%$. & $r$ & مـع الأم \\
\hline$\% 1 \ldots$ & 7 & المجموع \\
\hline
\end{tabular}

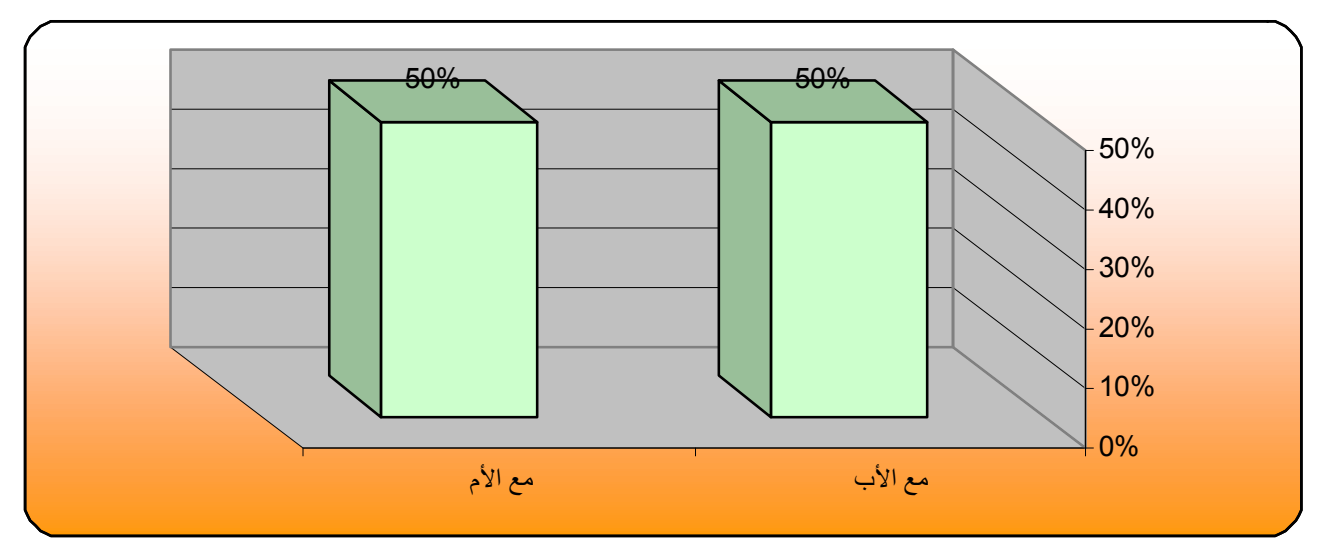

شكل ( 11 ) يوضح مع أي الوالدين يعيش الطفل

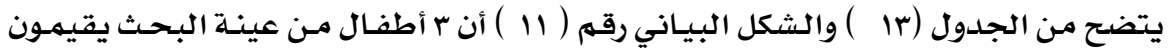

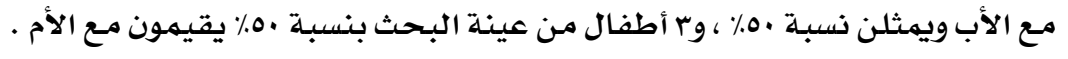




\begin{tabular}{|c|c|c|c|}
\hline \multicolumn{4}{|c|}{ جد ول ( عا ) الوزن النسبي لكيفية اكتشاف الموهبة لدى الأبناء } \\
\hline الترتيب & النسبـة المئويـة/. & الوزن النسبي & كيفية اكتشاف الموهبــ لدى الابناء \\
\hline الخامس & $\% 1 \cdot, r$ & $r+1$ & قدرات عقلية \\
\hline 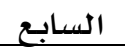 & $\%, \mathrm{~V}$ & $11 r$ & التحصيل \\
\hline 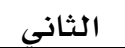 & $\% \backslash \wedge, \wedge$ & rvi & مواهب خاصدة \\
\hline الرابع & $\% 1 r, 9$ & $r V \varepsilon$ & ترشيح الوالدين \\
\hline السـادس & $\%$ & IVA & ترشيح المدرسـة \\
\hline 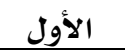 & $\%, Y, 7$ & EYo & سمات الشخصية الشية \\
\hline 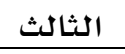 & $\% 17,1$ & mis & اختبـارات عقلية \\
\hline \multirow[t]{2}{*}{ الثامـن } & $\% \varepsilon, V$ & 94 & أنشطة لا صفية \\
\hline & $\% 1 \ldots$ & I9VY & المجموع \\
\hline
\end{tabular}

يتضـح أن أكثر الآراء حسول كيفيـة اكتشـاف الموهبـة لـدى الأبنـاء مـن وجهـة نظـر العينـه

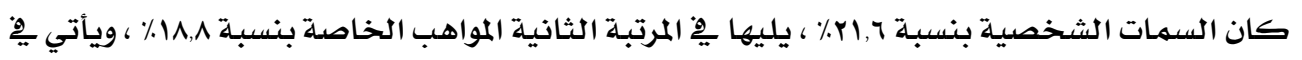

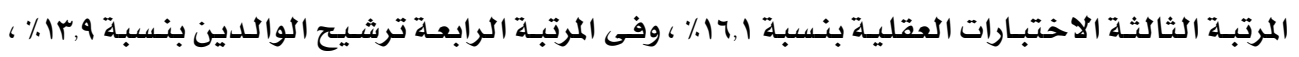

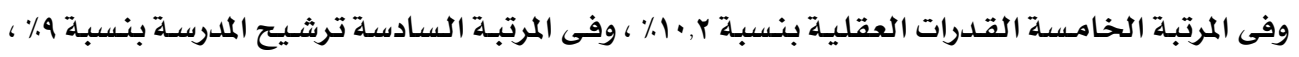

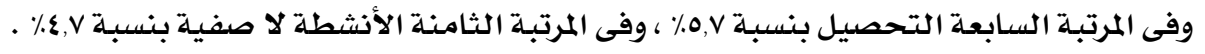
rا- الأوزان النسبية لأولوية الجهات المسئولة عن رعاية الموهوبين : جدول ( 10 ) الوزن النسبي لأولوية الجهات المسئولة عن رعاية الموهوبين

\begin{tabular}{|c|c|c|c|}
\hline الترتيب & النسبـة المئوية/. & الوزن النسبي & الجهات المسئولة عن رعاية الموهوبين \\
\hline 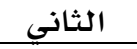 & $\%, r \cdot, 0$ & דוז & جهات تعليميـة \\
\hline الخامس & $\% 11,1$ & 199 & وزارات وإدارات حكومية \\
\hline 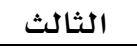 & $\% 1 V, \varepsilon$ & r. & نوادي وجمعيات \\
\hline الأول & $\%$ YY,Y & $\varepsilon \cdot r$ & 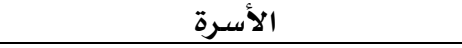 \\
\hline السـابـع & $\%, \mathrm{~V}$ & $1 \cdot r$ & مـراكز مهنيـة \\
\hline السـادس & $\% \vee, q$ & $1 \leqslant Y$ & قطاع خاص \\
\hline \multirow[t]{2}{*}{ الرابع } & $\% 1 \varepsilon, \wedge$ & YT\& & منظمـات إقليميـه ودوليـة \\
\hline & $\% 1 \ldots$ & IVAT & المجموع \\
\hline
\end{tabular}


يتضح أن أكثر الجهات المسئولة عن رعاية الموهوبين من وجهة نظر العينة كانت الأسرة المبرة

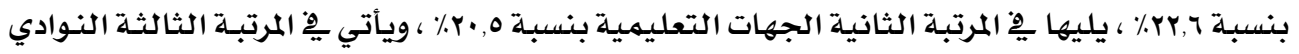

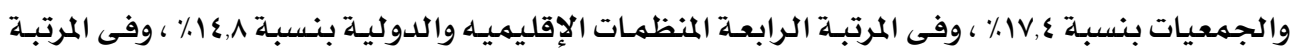

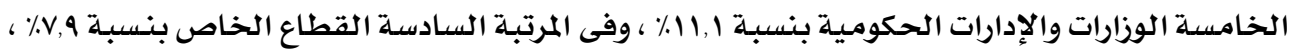

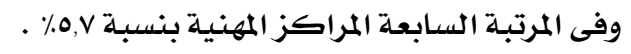

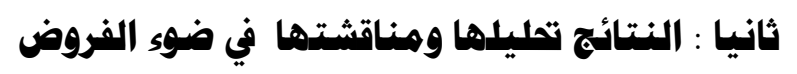

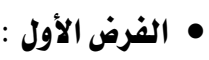

توجـد فـروق ذات دلادلة إحصائية بـين متوســ درجـات اسـر أفراد العينـة يِّ مستوى وعيهـا

بدورها ِِّ رعاية الطفل الموهوب تبعا لمتغيرات الدراسة دونة

وللتحقق من هذا الفرض تم تطبيق اختبار ( ) ) وحساب تحليل التباين لدرجات اسر أفراد

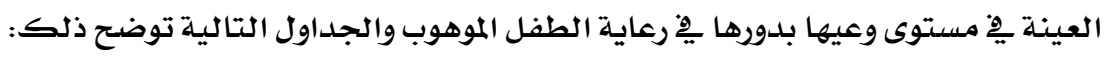

جدول ( 17 ) الفروق يْ متوسط درجات اسر أفراد العينة ِِ مستوى وعيها بدورها

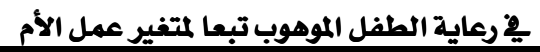

\begin{tabular}{|c|c|c|c|c|c|c|}
\hline الدلالة & قيمة & درجات & العينة & الانحراف & المتوسط الحسابي & عمل الآّم \\
\hline \multirow{2}{*}{ دال عند 0 •. • لصالح } & \multirow{2}{*}{$r, 190$} & \multirow{2}{*}{ Ar } & $1 \varepsilon$ & rוM, & $79,7 \leqslant Y$ & تعمل \\
\hline & & & $v$. & $Y \cdot, \wedge Y Y$ & $\wedge \varepsilon, \wedge \wedge 0$ & لا تعمل \\
\hline
\end{tabular}

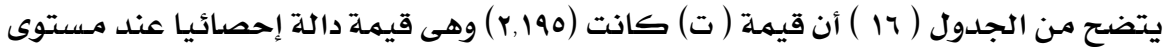

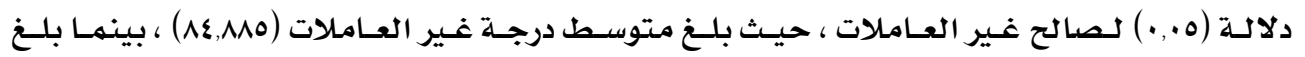

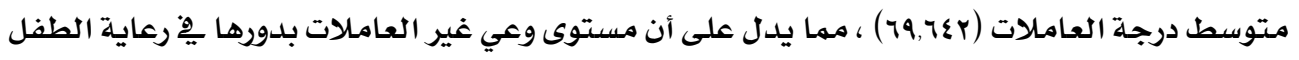

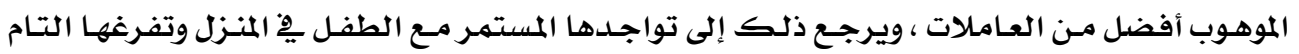

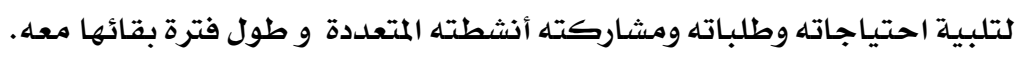

جدول ( IV ) تحليل التباين للدرجات اسر أفراد العينة فِ مستوى وعيها بدورها

ــ رعاية الطفل الموهوب تبعا لمتغير تعليم الأب

\begin{tabular}{|c|c|c|c|c|c|}
\hline الدلالة & قيمسة & درجات & متوسط المربعات & مجرموع المربعات & مستوى تعليهم \\
\hline \multirow{3}{*}{ ו•,••دال } & \multirow{2}{*}{$\varepsilon Y, \wedge \vee Y$} & $r$ & 17ror, IVI & $r Y 0.7, r \leqslant r$ & بين المجمهوعات \\
\hline & & 11 & $r \leqslant 7, \vee 0 \wedge$ & $Y \Lambda \cdot \Lambda V, \varepsilon \cdot V$ & داخل المجموعات \\
\hline & & ᄉr & & $7.094,10$. & المجموع \\
\hline
\end{tabular}


$\underline{\underline{ }}$

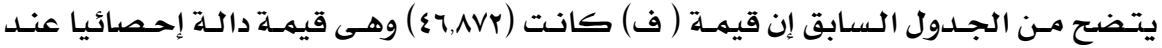

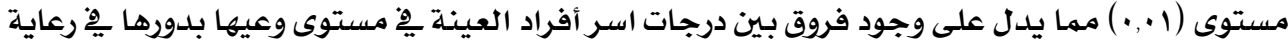

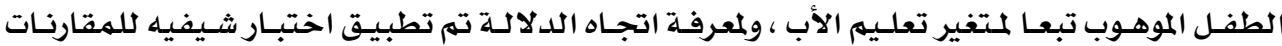

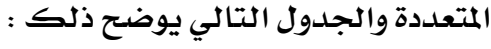

جدول ( 1 ) دلالة الفروق بين متوسطات مستوى وعي الاسرة بلدورها هِ رعاية الطفل الموهوب تبعا لمتغير تعليم الاب

\begin{tabular}{|c|c|c|c|}
\hline م= عالي & 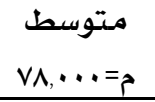 & منسخفض & مستوى تعليم الأب \\
\hline & & - & منـخفض \\
\hline & - & $*$ * YA,TTY & متتوسط \\
\hline- & $* *$ HY,TYq & $* 41$, Y97 & عالى \\
\hline
\end{tabular}

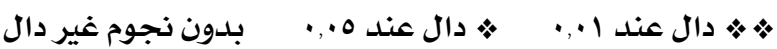

يتضح من جدول ( N ) ) وجود فروق يِّ استبيان مستوى وعي الأسرة بدورها يِّ رعاية أبنائها

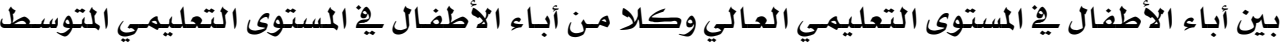

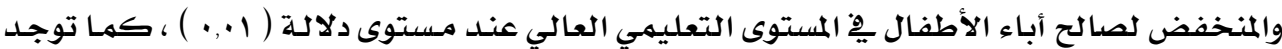

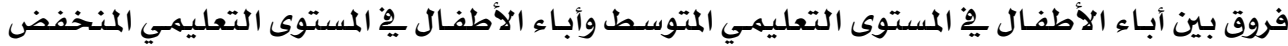

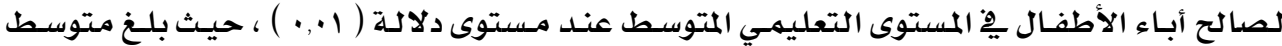

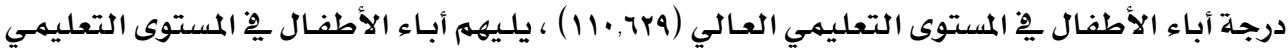

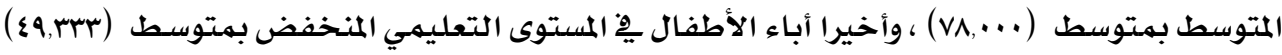

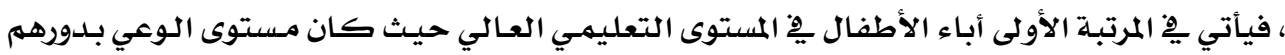

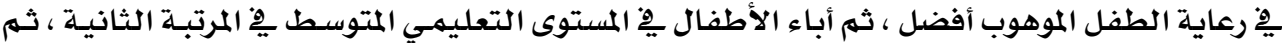

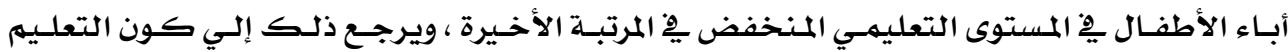

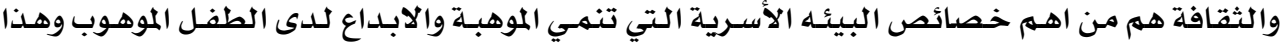

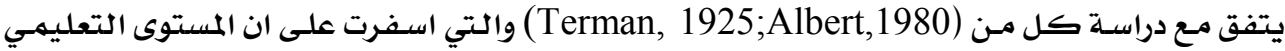

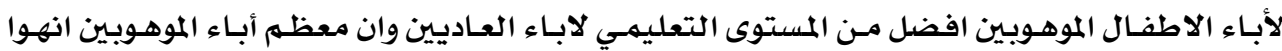




\section{جدول ( 19 ) تحليل التباين لدرجات اسر أفراد العينة}

ـِ مستوى وعيها بدورها بِ وعاية الطفل الموهوب تبعا لمتغير تعليم الأم

\begin{tabular}{|c|c|c|c|c|c|}
\hline الدلالة & قيمة & درجات & متوسط المربعات & مجرموع المربعات & مستوى تعليهم الأم \\
\hline \multirow{3}{*}{ מי•.• } & \multirow{2}{*}{ 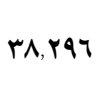 } & $r$ & $11 \wedge v \cdot, 7 \cdot 9$ & rrVEI, Y19 & بين المجمهوعات \\
\hline & & $\wedge 1$ & $r \cdot 9,9 V Y$ & Y01.V,V7q & داخل المجموعات \\
\hline & & Ar & & $\varepsilon \wedge \wedge \varepsilon \wedge, ৭ \wedge \wedge$ & المجموع \\
\hline
\end{tabular}

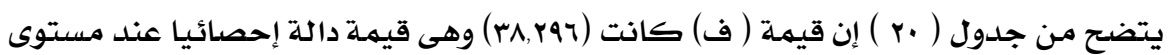

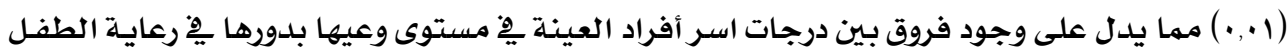

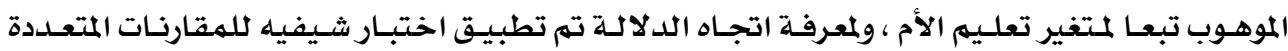
والجدول التالي يوضح ذلك:

جدول ( • ) دلالة الفروق بين متوسطات مستوى وعي الاسرة بدورها

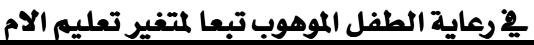

\begin{tabular}{|c|c|c|c|}
\hline م=عالي & 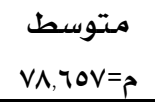 & من=سخفض & مستوى تعليه الأم \\
\hline & & - & منخفض \\
\hline & - & 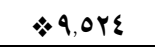 & متوسط \\
\hline - & $* * r V, r I V$ & $* \&\{7, V \leqslant 1$ & عالى \\
\hline
\end{tabular}

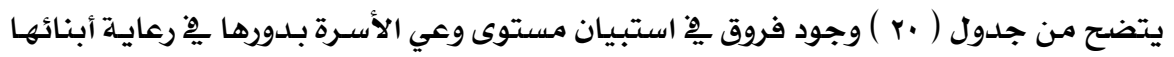

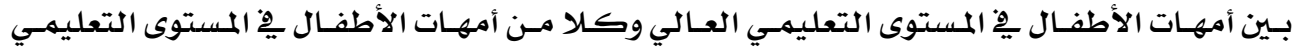

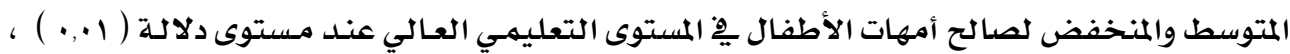

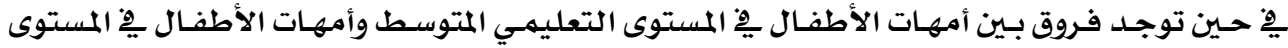

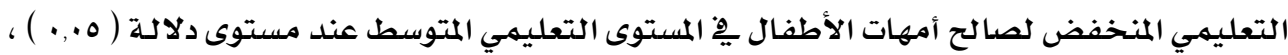

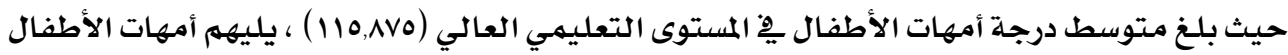

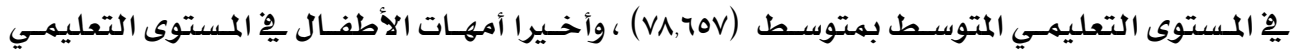

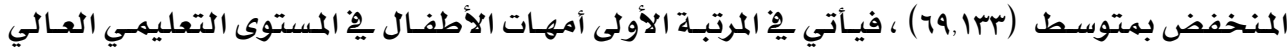

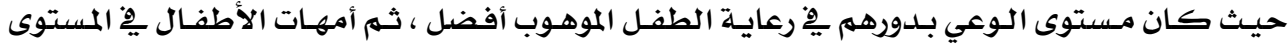

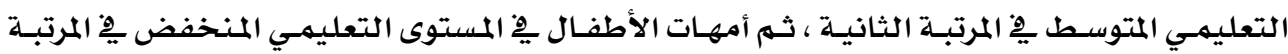

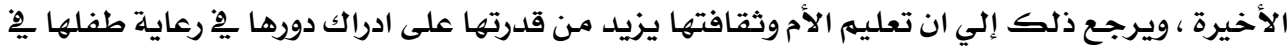

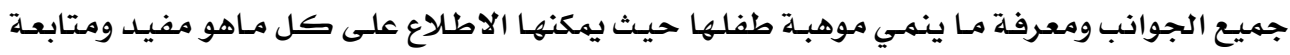
كل ما يستجد من دراسات هذا الجانب. 
جدول ( r ) ) تحليل التباين للدرجات اسر أفراد العينة فِ مستوى وعيها بدورها

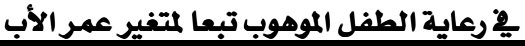

\begin{tabular}{|c|c|c|c|c|c|}
\hline الدلالة & قيمة & الحرجية & متتوسط المربعات & مجرموع المربعات & عمر الأب \\
\hline \multirow{3}{*}{ دال } & \multirow{2}{*}{ YT,IVA } & $r$ & Irrol,orr & $r \varepsilon V \cdot r, \cdot T \varepsilon$ & بينين المجموعات \\
\hline & & 11 & \&VI,Arq & YAYIA,VミT & داخل المجموعات \\
\hline & & $\Lambda r$ & & TraYI,NI. & المجموع \\
\hline
\end{tabular}

يتضح من جدول ( Y ) ) إن قيمة ( ف) كانت (rY,IVN) وهى قيمة دالة إحصائيا عند مستوى

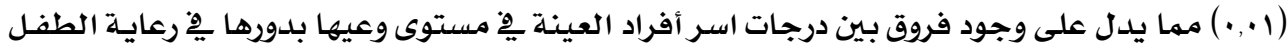

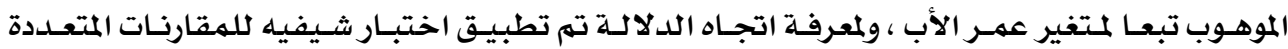
والجدول التالي يوضح ذلك :

جدول ( rr ) دالة الفروق بين متوسطات مستوى وعي الأسرة بدورها

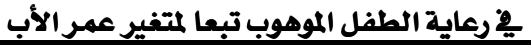

\begin{tabular}{|c|c|c|c|}
\hline مـن ·ع سنـه فأكثر & 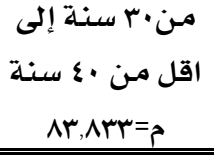 & 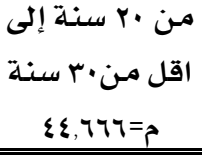 & عمر الأب \\
\hline & & - & من ·r سنـة إلى اقل من·r سنـة \\
\hline & - & $* \$ 49,177$ & من ·r سنـة إلى اقل مـن ·ع سنـة \\
\hline- & $r, 991$ & $* \& \varepsilon, 10 \mathrm{~V}$ & مـن ·ع سنه فأكثر \\
\hline
\end{tabular}

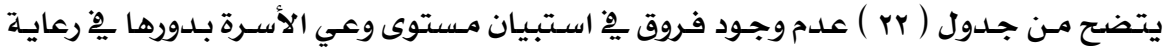

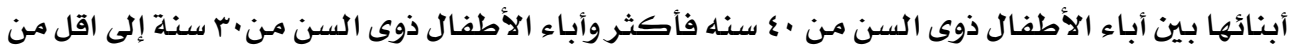

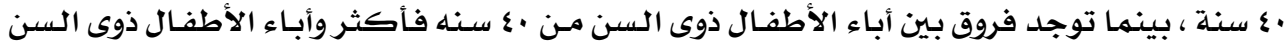

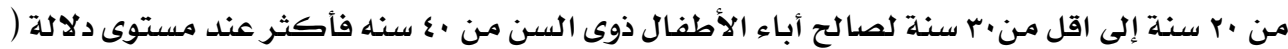

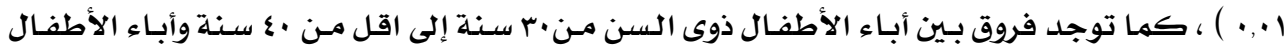

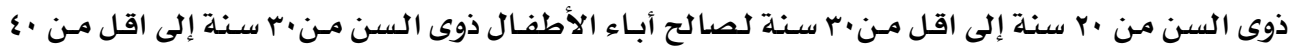

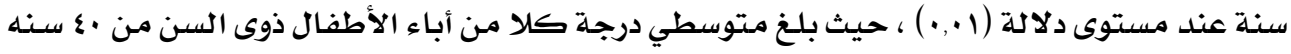

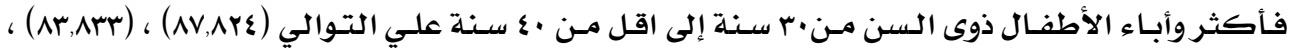

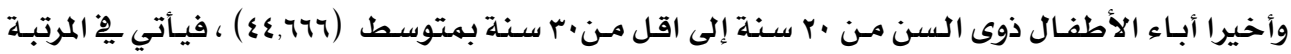

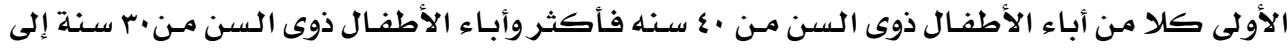

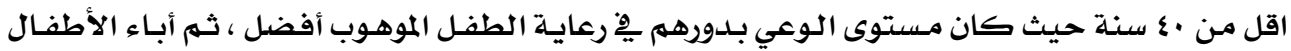

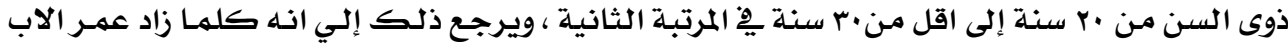




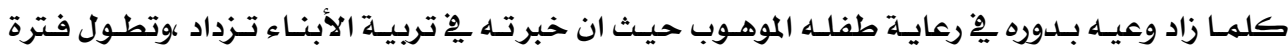

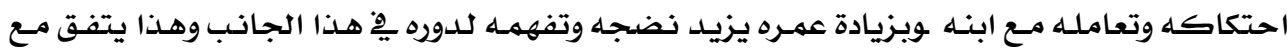

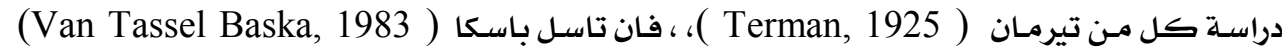

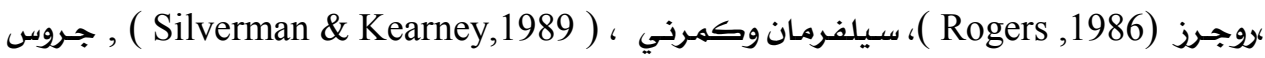

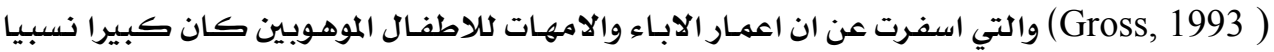

$$
\text { أي يِّ أواخر العشرينات وأوائل الثلاثينيات . }
$$

جدول ( rr ) تحليل التباين لدرجات اسر أفراد العينة فِ مستوى وعيها بدورها

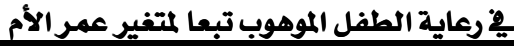

\begin{tabular}{|c|c|c|c|c|c|}
\hline الدلادلة & قيمة ( ف) & الحرجـات & متتوسط المربعات & مجموع المربعات & عمر الأم \\
\hline \multirow{2}{*}{ ו•,•• دال } & \multirow{2}{*}{$01,0 \leqslant Y$} & $r$ & $17.00, \mathrm{Vr \varepsilon}$ & $r Y 111,879$ & بين المججموعات \\
\hline & & $\wedge 1$ & $\mathrm{MIl}, 0 . \mathrm{V}$ & rOYrY, 1.r & داخل المجموعات \\
\hline & & $\wedge r$ & & OVY\&Y,OVY & المجموع \\
\hline
\end{tabular}

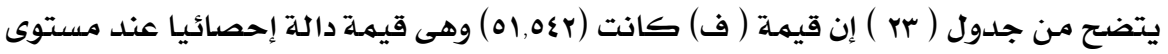

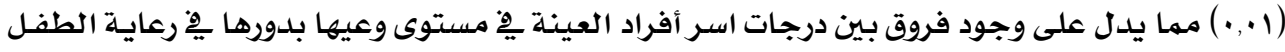

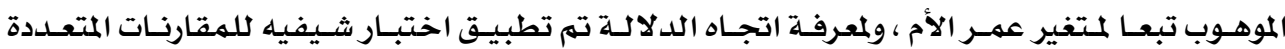
والجدول التالي يوضسح ذلك:

جدول ( ع ) د دلالة الفروق بين متوسطات مستوى وعي الاسرة بلدورها

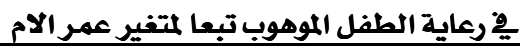

\begin{tabular}{|c|c|c|c|}
\hline 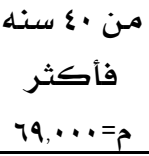 & 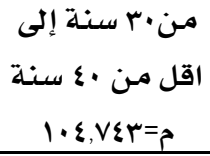 & 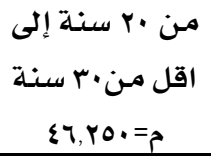 & عهـر الأم \\
\hline & & - & مـن ·r سـنـة إلى اقل مـن، سـنـة \\
\hline & - & $* 0 \wedge, \varepsilon 9$ & منـr سـنـة إلى اقل من ، ع سـنـة \\
\hline- & $* * r \Delta, v \varepsilon r$ & $*$ *r,VO. & من ·ع سنـه فأكثر \\
\hline
\end{tabular}

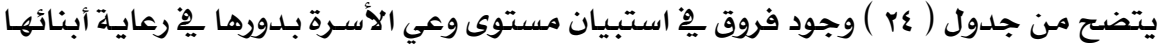

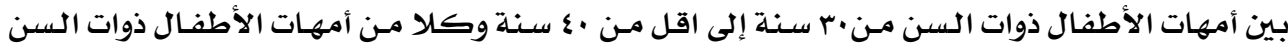

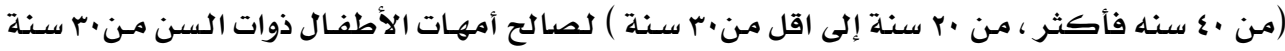

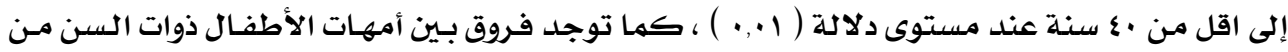

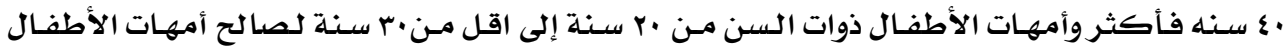

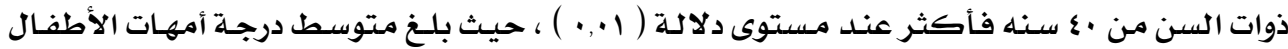




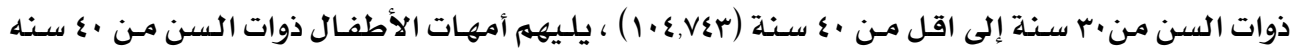

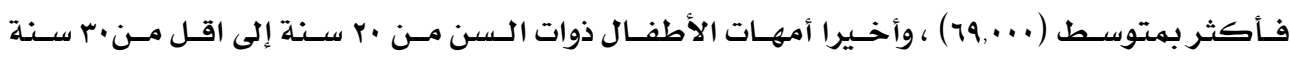

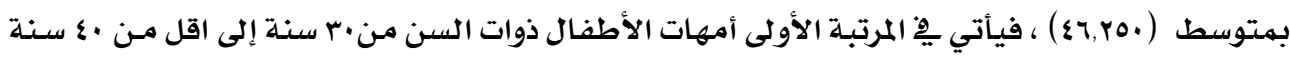

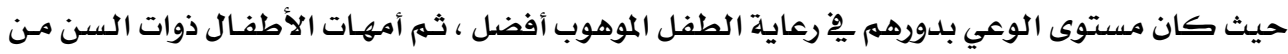

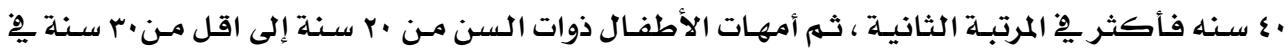

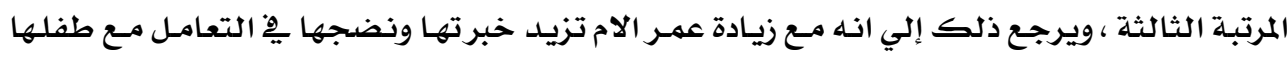
ويالتالي تكون اكثروعيا لدورها يفُ رعاية وحماية الطفل الموهوب.

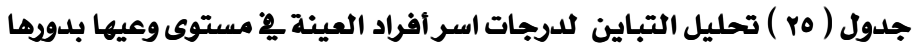

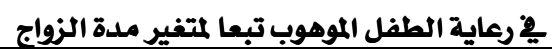

\begin{tabular}{|c|c|c|c|c|c|}
\hline الدلالة & قيمة (ف) & درجات & متوسط المربعات & مجموع المريعات & مدة الزواج \\
\hline \multirow{3}{*}{ ני•, } & \multirow{2}{*}{00,971} & $r$ & IrצTr,\&r. & rVqAV,rq. & بين المجموعات \\
\hline & & A. & YYT,YYI & $|N| \cdot 1,77 r$ & داخل المجموعات \\
\hline & & ي & & $07 \cdot 11,90 Y$ & المجموع \\
\hline
\end{tabular}

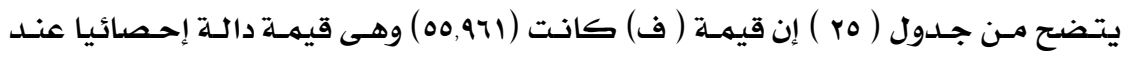

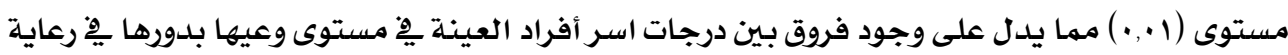

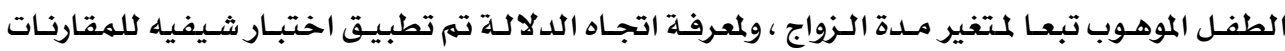

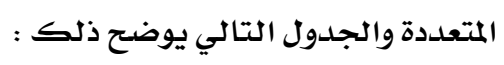

جدول ( r ) د دالالة الفروق بين متوسطات مستوى وعي الأسرة بدورها

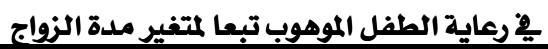

\begin{tabular}{|c|c|c|c|c|}
\hline من فأكثر 10 سنـة & من · •اقل من من 10 مـ سنوات إلي & من ه سنـوات إلي مـ م= • & مستوات من 0 & مدة الزواج \\
\hline & & & - & اقل من ه سنوات \\
\hline & & - & $\$ 7, r \cdot r$ & مـن ه سنـوات إلي اقل مـن · 1 سنوات \\
\hline & - & $*$ rV,Arr & \& & من · ا سنوات إلي اقل مـن 10 سـنة \\
\hline- & $* * r r, r r$ & $* \bullet \cdot, \wedge \circ \mathrm{V}$ & $* \circ 0 \vee 17$. & من 10 سنـة فأكثر \\
\hline
\end{tabular}

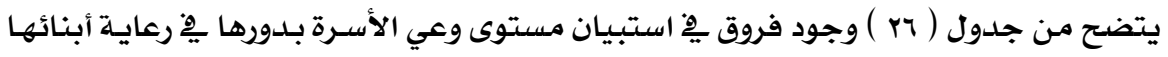

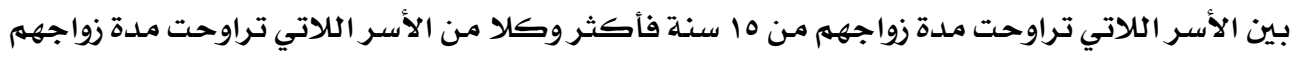

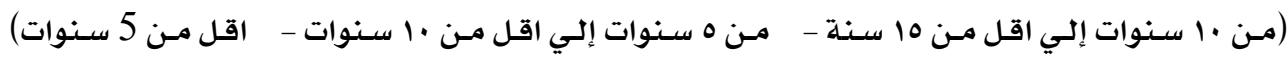

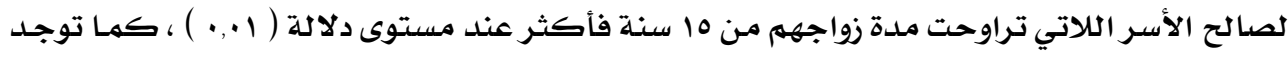




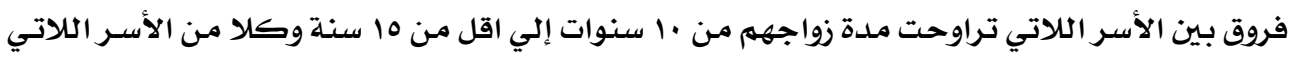

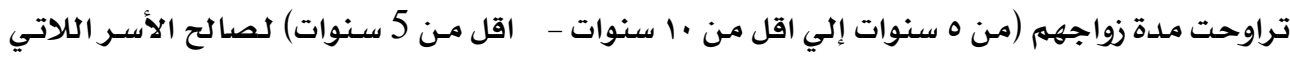

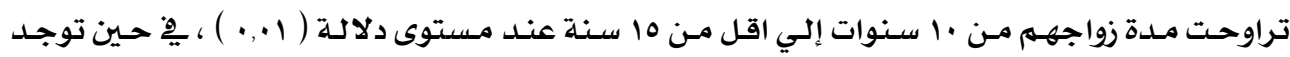

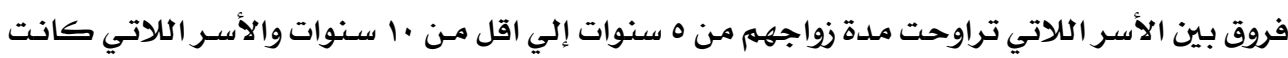

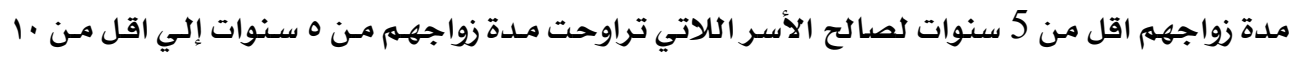

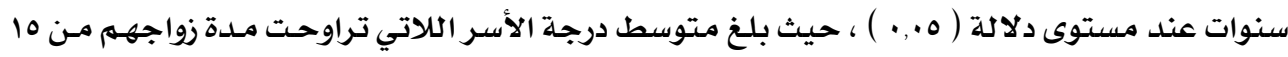

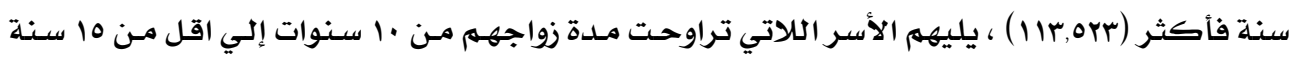

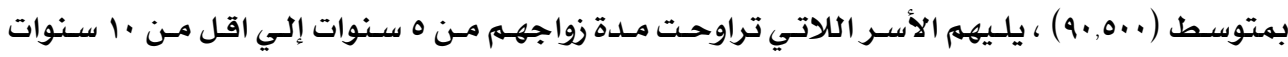

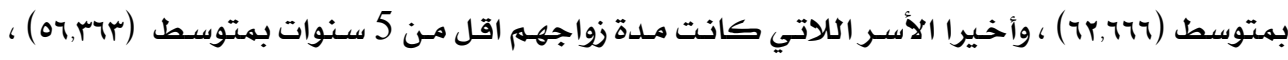

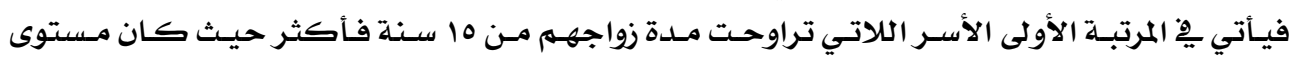

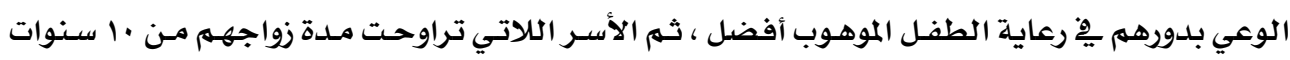

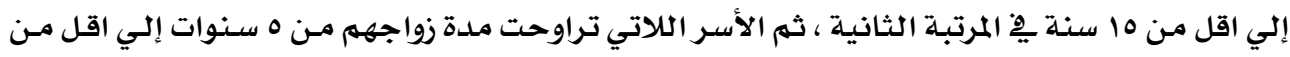

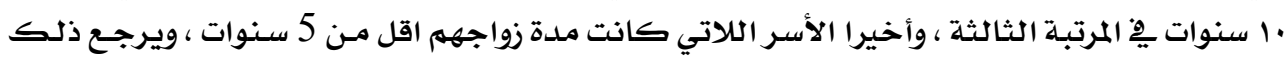

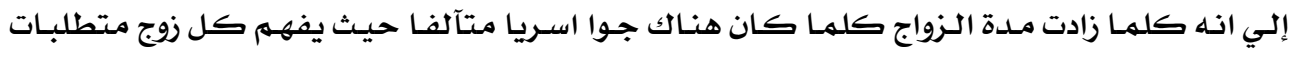

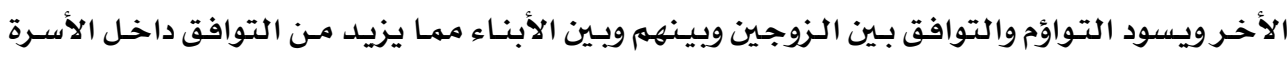

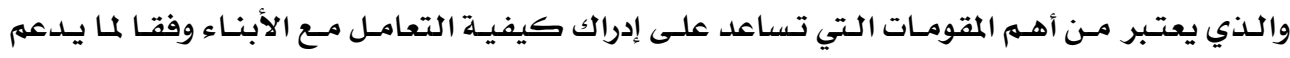

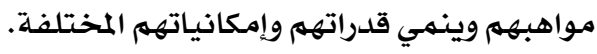

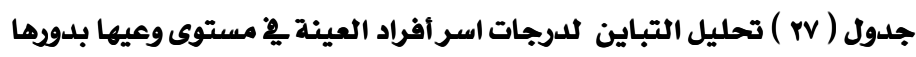

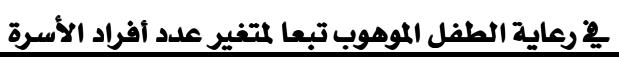

\begin{tabular}{|c|c|c|c|c|c|}
\hline الدلالة & قيمة ( ف) & درجات الحرية & متوسط المربعات & مجموع المربعات & عدد أفراد الأسرة \\
\hline \multirow{2}{*}{ 1..•• دال } & \multirow{2}{*}{$0 \wedge,\{01$} & r & $17 . .79 .09$ & rr. $1 Y, 1 M$ & بين المجموعات \\
\hline & & $\wedge 1$ & $r V r, A r V$ & YYMA.,VVO & داخل المجموعات \\
\hline & & $\Delta r$ & & O\&।QY,А৭Y & المجموع \\
\hline
\end{tabular}

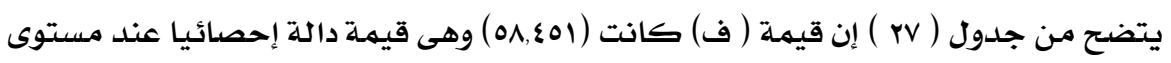

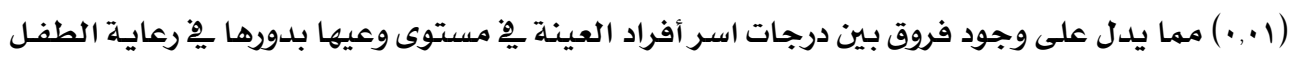

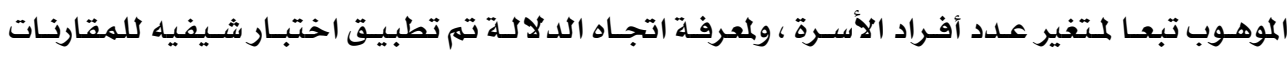
المتعددة والجدول التالي يوضح ذلك : 
جدول ( Y ) دلالة الفروق بين متوسطات مستوى وعي الأسرة بدورها

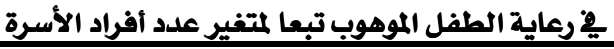

\begin{tabular}{|c|c|c|c|}
\hline م أفراد فأكثر & من ع أفراد إلي V أفراد & 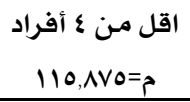 & عدد أفراد الأسـرة \\
\hline & & - & اقل من § أفراد \\
\hline & - & $*$ rl, rVo & من ₹ أفراد إلي V أفراد \\
\hline - & $* \nLeftarrow r \varepsilon, v 0$ & $\$ \otimes 00,80$. & ^ أفراد فأكثر \\
\hline
\end{tabular}

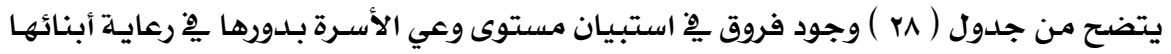

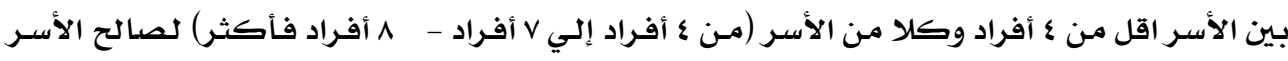

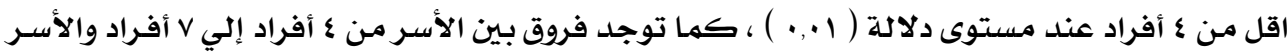

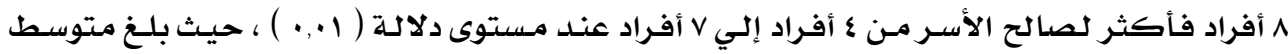

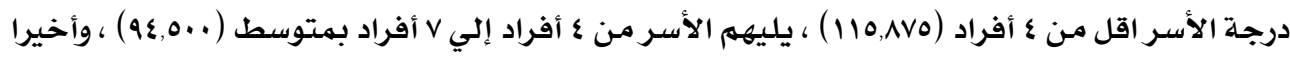

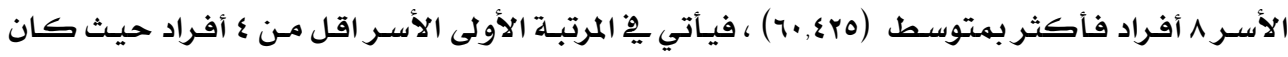

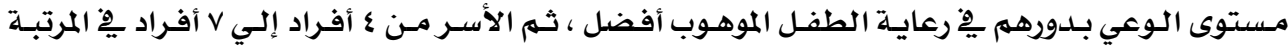

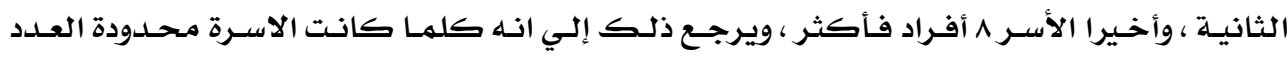

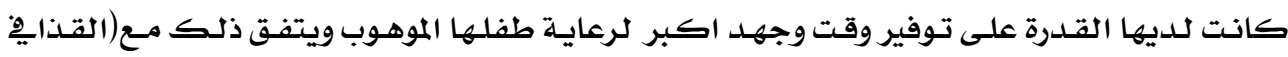
الجاء (Y....

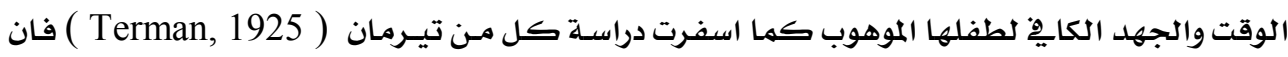

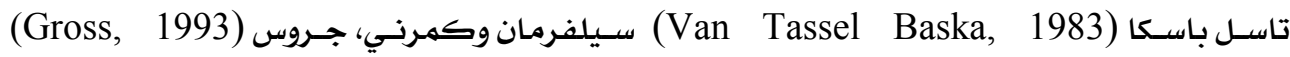

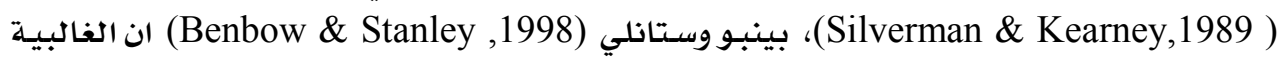

العظمى من أسر الأطفال الموهوبين بلغ عدد الأطفال فيها من اثنين. الى ثلاثة اطفال العال .

جدول ( ج ) تحليل التباين لدرجات اسر أفراد العينة يو مستوى وعيها بدورها

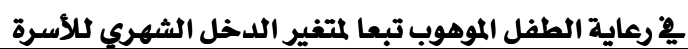

\begin{tabular}{|c|c|c|c|c|c|}
\hline الدلالة & قيمـة & درجـات & متوسط المربعات & مجرموع المربعات & الدخل الشهري \\
\hline \multirow{3}{*}{ מין } & \multirow{2}{*}{07,109} & r & IVET.,VYY & $r \varepsilon q r \mid, \varepsilon \varepsilon \varepsilon$ & بين المجموعات \\
\hline & & 11 & $\mu \cdot v, \cdot \Lambda \Lambda$ & $Y \leqslant \wedge \vee \leqslant, 171$ & داخل المجمبوعات \\
\hline & & $\Lambda \mu$ & & $09 \vee 90,7 \cdot 0$ & المجموع \\
\hline
\end{tabular}

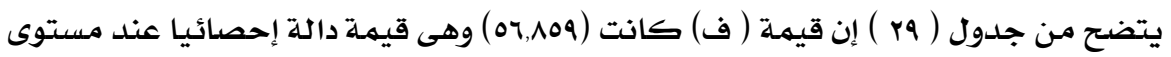

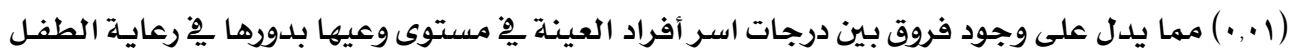


الموهوب تبعا لمتغير الدخل الشهري للأسـرة ، ولمعرفة اتجاه الدلالة تم تطبيق اختبـار شيفيه للمقارنات

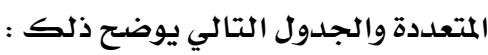

جدول ( r ) دلالة الفروق بين متوسطات مستوى وعي الأسرة بدورها

-

\begin{tabular}{|c|c|c|c|}
\hline م=رتصفع & مت م=وسط & منتخفض & الدخل الشهري للأسرة \\
\hline & & - & منخخف \\
\hline & - & $* * r r, 0 \wedge 0$ & متوسط \\
\hline - & $*$ *rr,q11 & $*$ \& ४ ₹१V & مـرتفـع \\
\hline
\end{tabular}

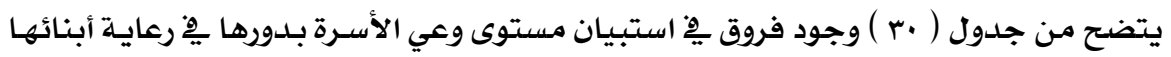

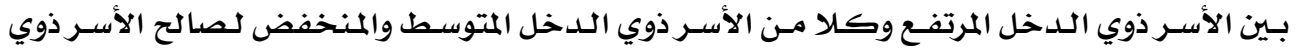

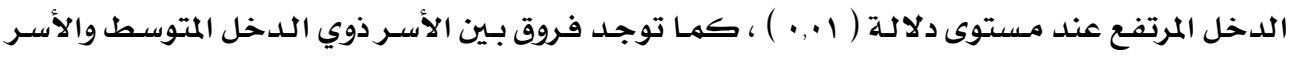

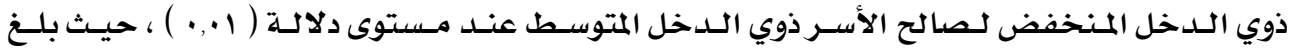

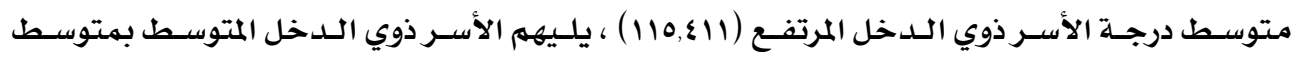

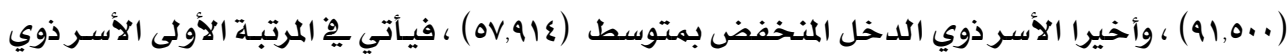

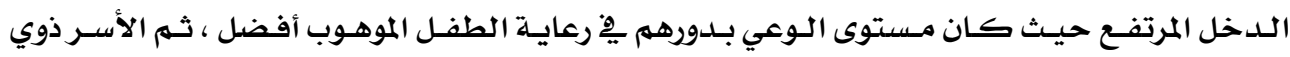

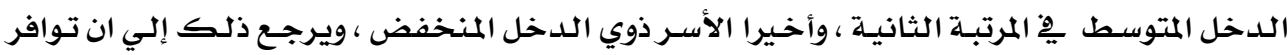

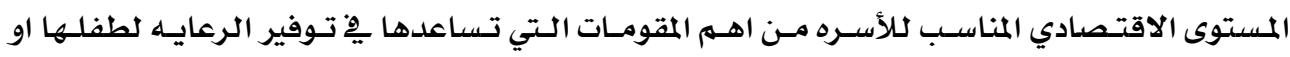

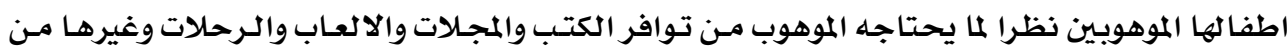

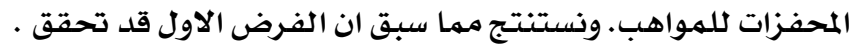
• • ب الفرض الثاني :

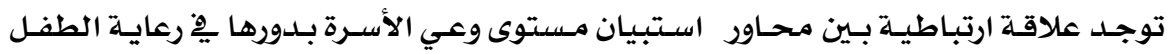
الموهوب ومتغيرات الدراسـة وللتحقق من صححة هذا الفرض تم عمل مصفوفة ارتباط بين محساور استبيان مستوى وعي

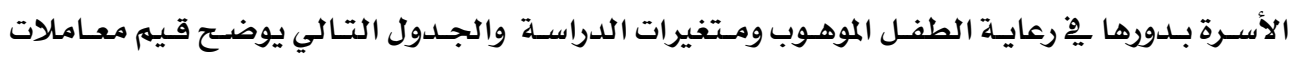
الارتباط : الاسترة بل 
جدول ( اس ) مصفوفة الارتباط بين محاور استبيان مستوى وعي الأسرة بلورها

- 2ِ رعاية الطفل الموهوب ومتغيرات الدراسة

\begin{tabular}{|c|c|c|c|c|c|c|}
\hline مستوى وعي الأسرة & الجاذب الثقافي & |الجانب الصحي & الجاظب العاطئ & الجانب النفسي & الاجتماعب الجانب & المتفيرات \\
\hline$\cdot$ - IAr & • YYY & $\cdot, 1 \leqslant 0$ & $\cdot, 11 \mathrm{~V}$ & rדו, & $\cdot .194$ & مدة الزواج \\
\hline$* *, \mathrm{T \wedge \vee}$ & $* * \cdot v \varepsilon r$ & $\$ \cdot 7 \cdot 1$ & $* \bullet \cdot V \cdot \varepsilon$ & \& צ & $* *$, VTV & عمر الأب \\
\hline$* *$, vor & $* * \cdot 9 \cdot r$ & $\$, 7 \leqslant 1$ & םrד, • & $* *, \wedge \leqslant \wedge$ & $* *$, Aro & عمر الأم \\
\hline$* *$, , q $\varepsilon$ & $* * \cdot 9 \mathrm{rr}$ & $* *, \mathrm{~V} \wedge \Lambda$ & $* * \cdot \Lambda \cdot r$ & $* * .91 \varepsilon$ & $* * \cdot \wedge T r$ & تعليه الأب \\
\hline **, *, מrr & $* * \cdot \wedge \wedge \mathrm{T}$ & $* * \cdot$ VAr & $* *, q \leqslant r$ & $* * \cdot \wedge \vee 1$ & $* *, 100$ & تعليم الأم \\
\hline$\cdot|| v \mid$ & - & $\cdot, Y 10$ & • 10Y &., 198 & - & عهل الأب \\
\hline • & $\cdot, 1 M \wedge$ & $\cdot, 119$ & $\cdot, r \cdot r$ & $\cdot, 1 \leqslant V$ & מrr, & عمل الأم \\
\hline$* * \cdot \wedge 94 \quad-$ & $* * \cdot 911-$ & $* * \cdot v \varepsilon r \quad-$ & \&.T.T- & $* *, 110$ & $* \bullet, \vee 91$ & عدد أفراد الأسرة \\
\hline$* *, \wedge \circ \mathrm{r}$ & $\$ .719$ & $* * \cdot V Y \varepsilon$ & $* * \cdot q \cdot v$ & צ צ • • & $* * \cdot \mathrm{VVr}$ & الدخل الشهري للأسرة \\
\hline$\cdot .171$ & $\cdot, Y \backslash I$ & $\cdot, 1 \vee 0$ & $\cdot, 11 r$ & •, YYA & $\cdot 114$ & عمر الأبناء \\
\hline
\end{tabular}

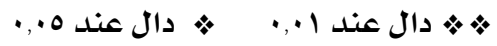

يتضـح من الجدول ( اب ) وجود علاقة ارتباط طردي بين محاور استبيان مستوى وعي الأسرة

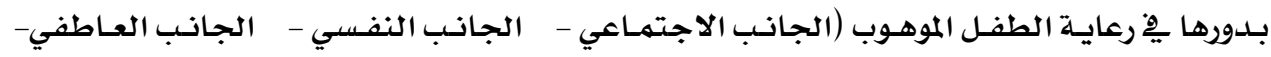

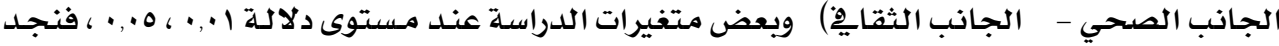

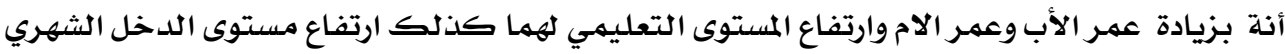

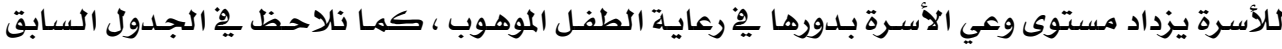

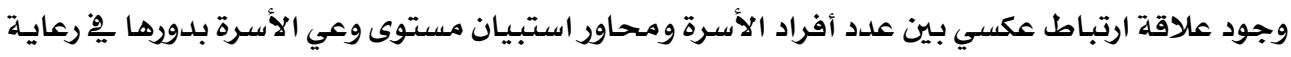

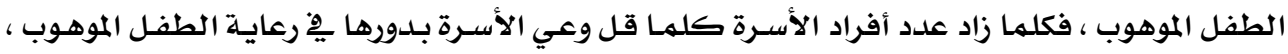

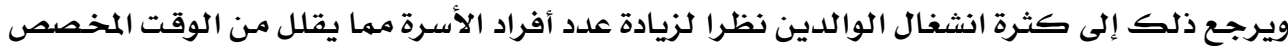

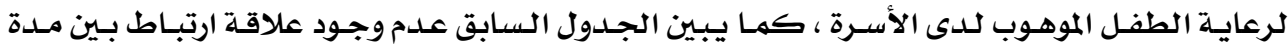

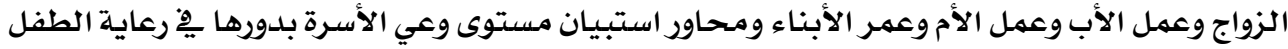

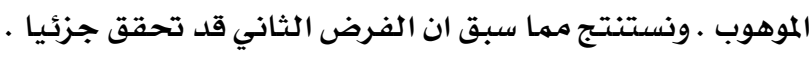

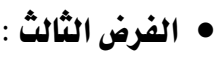

تختلف نسبة مشاركة العوامل المؤثرة على وعي الأسـرة بلدورها ِِِِ رعاية الطفل الموهوب 
وللتحقق من هذا الفرض تم حساب الأهمية النسبية باستخدام معامل الانحدار(الخطوة

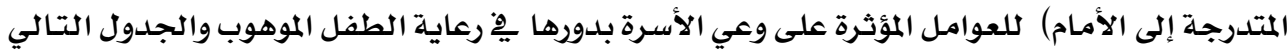

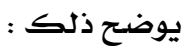

جدول ( rr ) الأهمية النسبية باستخدام معامل الانحدار(الخطوة المتدرجة إلى الأمام) للعوامل المؤثرة على وعي الأسرة بلورها ـِ رعاية الطفل الموهوب

\begin{tabular}{|c|c|c|c|c|c|c|c|c|}
\hline الدلالة & قيمة ت ت) & معامل الانحدار & الدلالة & قيمة ف) & نسبة الششاركة & معامل الارتباط & المتفير المستقل & المتفير التابع \\
\hline$\cdot, \cdot 1$ & $11, \cdot 71$ & $\cdot, \Lambda \vee \vee$ & $\bullet,+1$ & rYY,รYร & $\cdot, \Lambda Y r$ & •, 9T8 & تعليه الأب & وعي الأسرة \\
\hline$\bullet,+1$ & $1 \cdot$, rAY & $\cdot, 799$ & $\bullet,+1$ & $1 \cdot V, \wedge 9 r$ & - , yar & •, Arr & تعليم الأم & بلدورها في \\
\hline$\cdot, \cdot 1$ & $V, 991$ & -, ova & $\bullet,+1$ & $7 r, \wedge 07$ & $\cdot, 0 V_{1}$ & $\cdot, \mathrm{YOY}$ & عمر الأم & رعاية الطفل \\
\hline$\cdot, \cdot 1$ & $7,0 \leqslant \xi$ & •, ह४१ & $\cdot,+1$ & $\{r, \wedge Y \wedge$ & $\cdot,\{Y Y$ & $\cdot$, YAV & عمر الأب & الموهوب \\
\hline
\end{tabular}

يتضح من الجدول السابق إن تعليم الأب كان مـن أكثر العوامل المؤثرة على وعي الأسرة

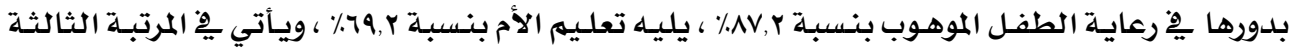

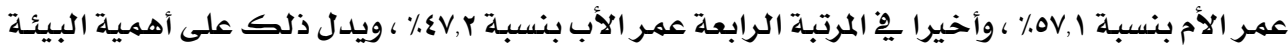

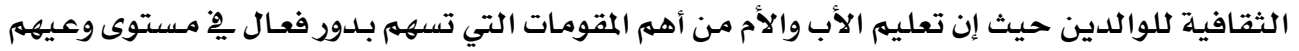

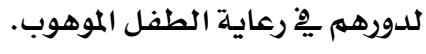

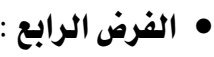
تختلف الأوزان النسبية لأولوية " جوانب " وعي الأسرة بدورها يِّ رعاية الطفل الموهوب

$$
\text { وللتحقق من هذا الفرض تم إعداد جدول الوزن النسبي التالي : }
$$

جدول (rr ) الوزن النسبي لأولوية جوانب وعي الأسرة بدورها يِّ رعاية الطفل الموهوب

\begin{tabular}{|c|c|c|c|}
\hline الترتيب & النسبة المئوية./ & الوزن النسبي & جوانب رعاية الأسرة للطفل الموهوب \\
\hline الرابع & $\% 1 \xi, \vee$ & IrA & الجانب الاجتماعي \\
\hline الأول & $\%$ \% Y, A & $r \cdot \Lambda$ & الجـانب النفسي \\
\hline 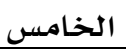 & $\% 1 \cdot, 1$ & 1.1 & الجانب العاطفي \\
\hline 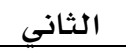 & $\%$ \%r,q & rrs & الجانب الصحي \\
\hline الثالث & $\% 1 \vee, \Lambda$ & $17 \mathrm{~V}$ & الجانب الثقاِِِ \\
\hline & $\% 1 \ldots$ & $94 \mathrm{~A}$ & المجموع \\
\hline
\end{tabular}

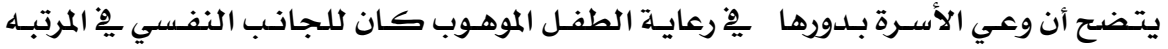

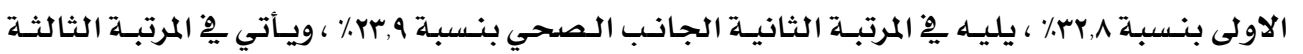

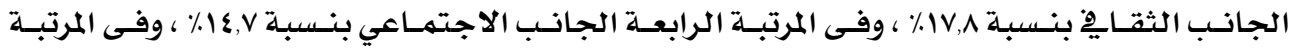

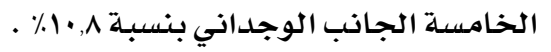




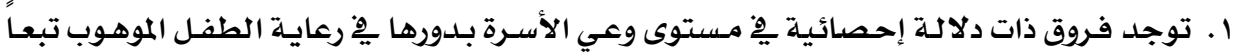

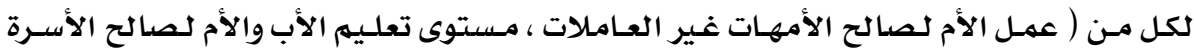

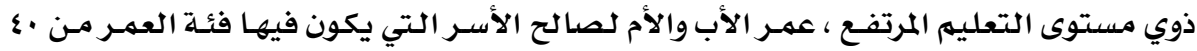

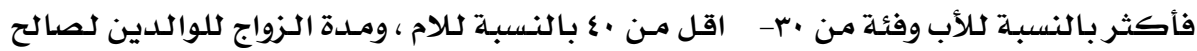

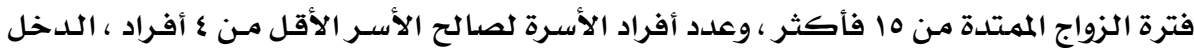

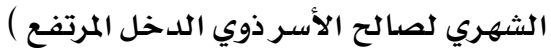

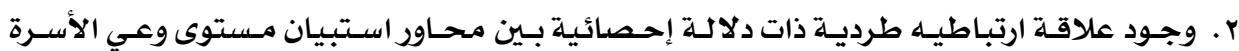

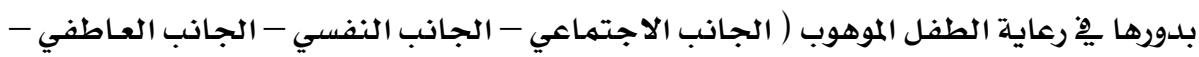

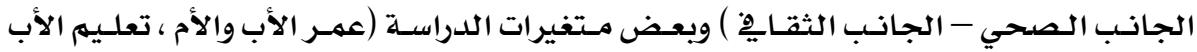

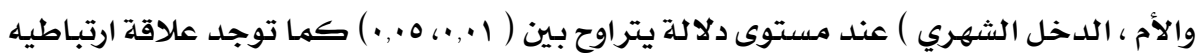

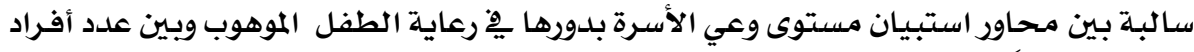

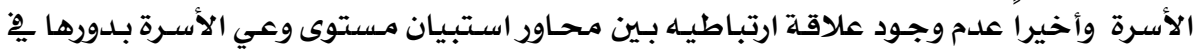
رعاية الطفل الموهوب وكل من مدة الزواج وأعمار الأبناء .

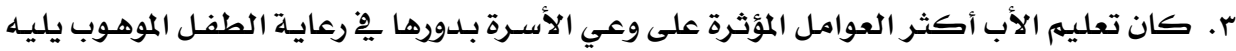

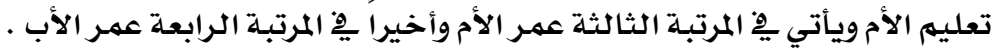

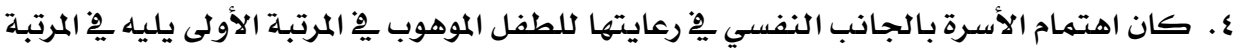

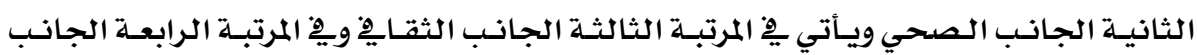

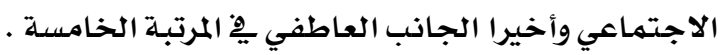

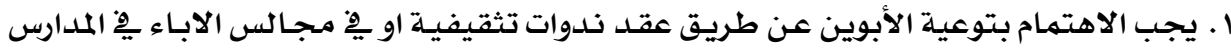

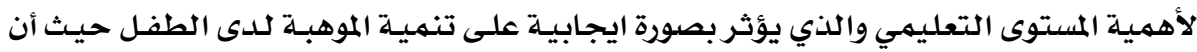
الأبوين المتعلمين يكونان اقدر على توفير بيئة ميسرة لتنمية الموهبة.

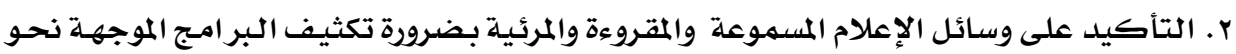
توجيه الأسرة بكيفية اكتشاف موهبة الأطفال وتعريفهم بالجهات المسئولة عن ذلك الكائل

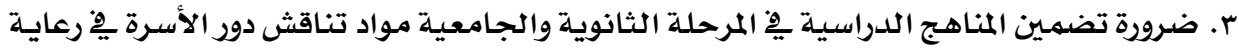
واكتشاف الموهوبين وذلك لإعداد جيل جديد واعي لأهمية هذا الدور . لمادية 


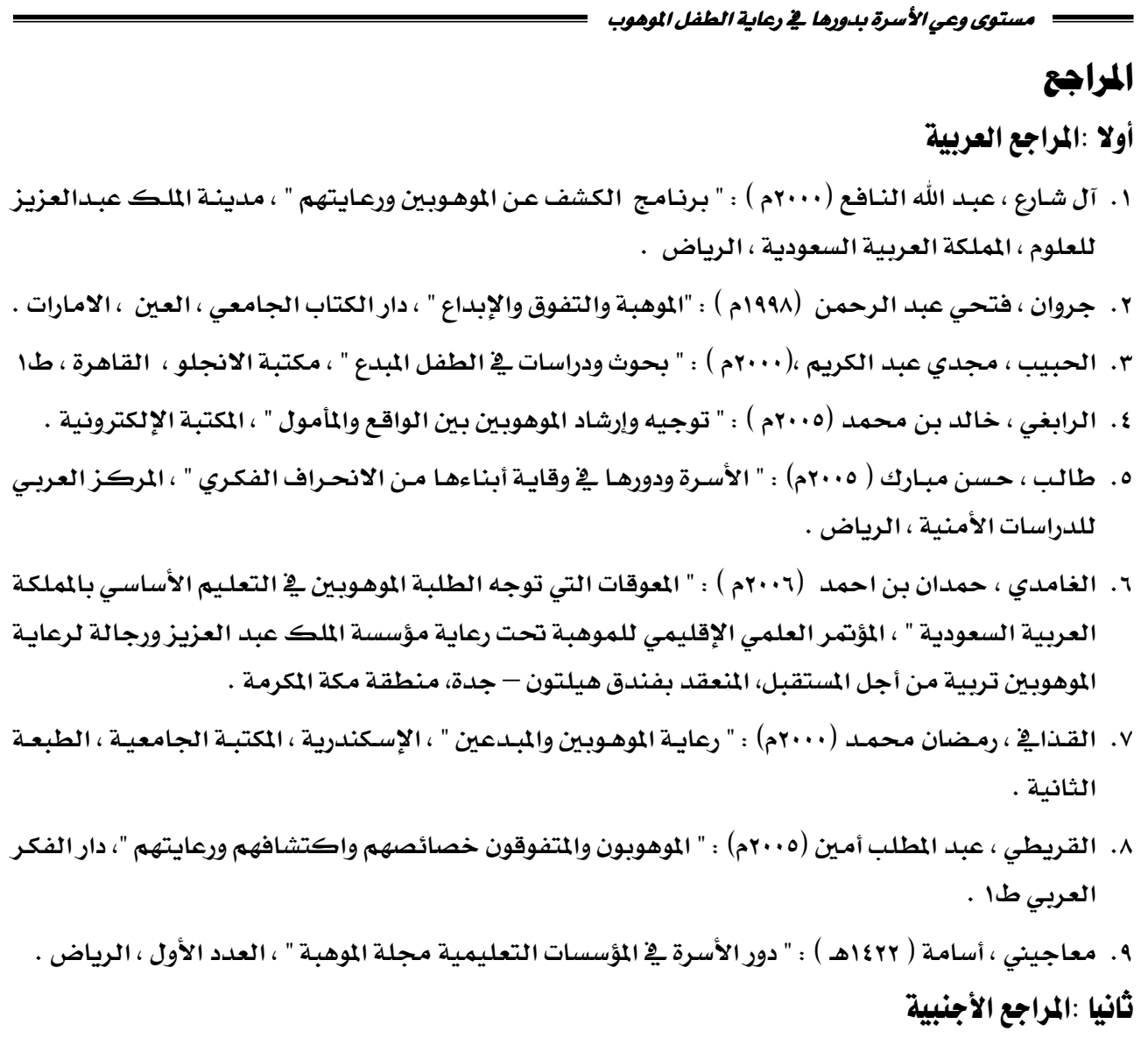

10. Albert, R.S. (1980) : "Family position and the attainment of eminence", A study of special family positions and special family experiences . Gifted Child Quarterly . 24(2) .87-95.

11. Benbow ,C.P.\& Stanley ,J.C (1980) : "Intellectually talented students" , family profiles. Gifted Child Quarterly, 24(3),119-122 .

12. Cornell, D. (1983) : " Gifted children", The impact of positive labeling on the family system. American Journal of Orthopsychiatry.

13. Gross, M. U. M. (1993) : "Exceptionally gifted children", London Routledge .

14. Porter , Louis ,(1999 ) : "Gifted young children" , guide for teachers and parents. Backing ham uk, open university press. 


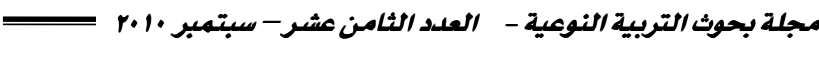

15. Rogers, M. T. (1986) : " A comparative study of developmental traits of gifted and average children " , Unpublished doctoral dissertation, University of Denver, Denver, CO.

16. Silverman, L. K., \& Kearney, K. (1989): " Parents of the extraordinarily gifted" , Advanced Development.

17. Terman, L. M. (1925) :" Genetic studies of genius" , Vol. 1. Mental and physical traits of a thousand gifted children. Stanford, CA: Stanford University Press.

18. VanTassel-Baska, J. (1983) : "Statewide replication in Illinois of the Johns", Hopkins Study of Mathematically Precocious Youth. In C. P. Benbow \& J. C. Stanley (Eds.), Academic precocity: Aspects of its development. Baltimore, MD: Johns Hopkins University Press 